\title{
OF MICE AND ACADEMICS: \\ EXAMINING THE EFFECT OF OPENNESS ON INNOVATION
}

\author{
Fiona Murray \\ Philippe Aghion \\ Mathias Dewatripont \\ Julian Kolev \\ Scott Stern \\ Working Paper 14819 \\ http://www.nber.org/papers/w14819 \\ NATIONAL BUREAU OF ECONOMIC RESEARCH \\ 1050 Massachusetts Avenue \\ Cambridge, MA 02138 \\ March 2009
}

The views expressed herein are those of the author(s) and do not necessarily reflect the views of the National Bureau of Economic Research.

NBER working papers are circulated for discussion and comment purposes. They have not been peerreviewed or been subject to the review by the NBER Board of Directors that accompanies official NBER publications.

(C) 2009 by Fiona Murray, Philippe Aghion, Mathias Dewatripont, Julian Kolev, and Scott Stern. All rights reserved. Short sections of text, not to exceed two paragraphs, may be quoted without explicit permission provided that full credit, including $\odot$ notice, is given to the source. 
Of Mice and Academics: Examining the Effect of Openness on Innovation

Fiona Murray, Philippe Aghion, Mathias Dewatripont, Julian Kolev, and Scott Stern

NBER Working Paper No. 14819

March 2009

JEL No. J30

\begin{abstract}
$\underline{\text { ABSTRACT }}$
Scientific freedom and openness are hallmarks of academia: relative to their counterparts in industry, academics maintain discretion over their research agenda and allow others to build on their discoveries. This paper examines the relationship between openness and freedom, building on recent models emphasizing that, from an economic perspective, freedom is the granting of control rights to researchers. Within this framework, openness of upstream research does not simply encourage higher levels of downstream exploitation. It also raises the incentives for additional upstream research by encouraging the establishment of entirely new research directions. In other words, within academia, restrictions on scientific openness (such as those created by formal intellectual property (IP)) may limit the diversity and experimentation of basic research itself. We test this hypothesis by examining a "natural experiment" in openness within the academic community: NIH agreements during the late 1990s that circumscribed IP restrictions for academics regarding certain genetically engineered mice. Using a sample of engineered mice that are linked to specific scientific papers (some affected by the NIH agreements and some not), we implement a differences-in-differences estimator to evaluate how the level and type of follow-on research using these mice changes after the NIH-induced increase in openness. We find a significant increase in the level of follow-on research. Moreover, this increase is driven by a substantial increase in the rate of exploration of more diverse research paths. Overall, our findings highlight a neglected cost of IP: reductions in the diversity of experimentation that follows from a single idea.
\end{abstract}

\author{
Fiona Murray \\ MIT \\ Sloan School \\ 50 Memorial Drive \\ Cambridge, MA 02142 \\ fmurray@mit.edu \\ Philippe Aghion \\ Department of Economics \\ Harvard University \\ 1805 Cambridge St \\ Cambridge, MA 02138 \\ and NBER \\ paghion@fas.harvard.edu \\ Mathias Dewatripont \\ Free University \\ mdewat@ulb.ac.be
}

\author{
Julian Kolev \\ Department of Economics \\ Harvard University \\ 1805 Cambridge St \\ Cambridge, MA 02138 \\ kolev@fas.harvard.edu \\ Scott Stern \\ Management and Strategy Department \\ Kellogg School of Management \\ 2001 Sheridan Road \\ Evanston, IL 60208 \\ and NBER \\ s-stern2@northwestern.edu
}




\section{Introduction}

The past three decades have seen a significant increase in the scope of formal intellectual property (IP) rights, such as patents, over knowledge traditionally maintained in the public domain (Mowery, et al 2001; Heller 2008). For example, American universities are granted over 3,000 U.S. patents each year and maintain a portfolio of over 40,000 patents (see Owen-Smith \& Powell, 2003). This dramatic expansion in IP rights over the earliest stages of research has caused widespread debate about the effectiveness of incentives for innovation (Scotchmer 1991, 1996). This debate is grounded in the notion that innovation is a step-by-step process in which discoveries generated in one stage serve as essential inputs into the next. The implications of expanding IP rights in the earliest stages of the innovation process are mixed. On the one hand, earlystage IP may be important to encourage the establishment of new research lines, since upstream researchers can thereby avoid expropriation by downstream researchers (Scotchmer, 1996). On the other hand, by requiring downstream innovators to contend with a large number of fragmented upstream IP rights, their projects may suffer from "gridlock" as a result of transaction costs and complexity (Heller \& Eisenberg 1998; Heller 2008).

By highlighting a single step-by-step research line the current debate abstracts away from two fundamental features of knowledge. First, a single upstream idea can, in principle, be applied across multiple later-stage domains and applications (Breshnahan \& Trajtenberg 1995, Rosenberg \& Trajtenberg 2001). In other words, ideas are non-rivalrous. Second, it may be extremely difficult in advance to precisely articulate the diversity and range of applications arising from a given upstream idea (Rosenberg 1996). Different individuals may have different perceptions regarding the main application of an idea or the follow-on research projects they would prefer to pursue. In other words, rather than focusing exclusively on the value generated along a single line, we argue that it is important to recognize that multiple researchers may seek to pursue a diverse range of exploratory "horizontal " follow-on experiments each of which may itself initiate new (potentially unanticipated) research lines.

What then is the role played by upstream IP rights when follow-on research includes both horizontal exploration as well as vertical exploitation? Interestingly, while prior research highlights the potential for gridlock arising from an upstream patent "thicket," little attention has been paid to the interaction between the openness of scientific knowledge and the diversity of scientific experimentation across a range of research lines. In this paper we examine the impact of changes in openness on the level and nature of scientific work in a setting in which diversity of scientific experimentation is particularly salient - academic research. Our analysis builds on recent research exploring the distinctive incentives and control rights provided by the institutional regime for research in academia as compared to industry (David and Dasgupta 1994, David 2001ab, David 2003).

More specifically, we take as a starting point the multi-stage research model developed by Aghion, Dewatripont \& Stein (2007), who emphasize the role 
of freedom for researchers - defined as the granting of control rights allowing researchers to select their research direction. Then we analyze the role of openness in that framework. In this setting, openness not only impacts innovation incentives within a given research line but also encourages exploration and investment in new and speculative research directions. We identify three main channels whereby openness can influence the level and nature of scientific research. First, by reducing the costs of accessing key research inputs, openness encourages new researchers to enter, thus increasing the diversity of academic research participants ${ }^{1}$. Second, openness makes researchers with high levels of freedom (academics) more likely to engage in experiments that broaden the horizontal diversity of research lines, in part because subsequent openness implies that their research can itself have subsequent impact across a wide range of research lines. Finally, there is the expropriation effect whereby an increase in the level of openness of an upstream research reduces the costs associated with the exploitation of that tool in research along a given vertical research line. Overall, our theoretical discussion suggests that, particularly in research settings characterized by high levels of freedom, openness not only increases the overall flow of research output, it should also be closely associated with the establishment and exploration of entirely new research lines. Moreover, while openness should affect both basic and applied research, the impact on basic research will, we predict, dominate when researchers in the pre-openness period face high fixed costs of initiating a new line of research. In contrast, the increase in applied research will dominate when significant basic research has already been conducted.

We evaluate these empirical implications by taking advantage of a "natural experiment" in openness that occurred in the late 1990s in the field of mouse genetics. The experiment resulted from two Memoranda of Understanding (MoU) between DuPont and the National Institutes of Health (NIH) regarding the ability of academic researchers to gain access to hundreds of genetically engineered mice developed using two types of technology (Cre-Lox and Onco, respectively) each covered by patents owned or licensed by DuPont. Prior to the NIH-MoUs, DuPont had adopted stringent restrictions on use of the mice for academic research. However, the MoUs lifted these restrictions by implementing a simple contract, providing a royalty-free and costless license that specifically removed any claims to reach-through rights on downstream research, and ensuring that the mice covered under the patents would be made available through the Jackson Laboratory (the world's single largest non-profit repository for research mice). The NIH-MoUs constitute an openness shock for the mouse genetics research community: Prior to the MoUs research tools covered by the patents - hundreds of varieties of Cre-lox or Onco mice developed in the early 1990s - were subject to stringent restrictions in openness. After the MoUs they suddenly became widely accessible to the entire academic research community.

Our empirical approach takes advantage of key aspects of this natural ex-

\footnotetext{
${ }^{1}$ Note that in our analysis we do not deal with the complementary issue of how to finance and/or reward the discovery of the initial research input. This could happen either through publicly subsidized research or through public buy-outs of (private) patents as in Kremer (1998).
} 
periment to develop and implement a differences-in-differences estimate of the impact of the NIH-MoU openness experiment on both the level and nature of follow-on research. First, each genetically engineered mouse is associated with a journal article that describes its initial development; as such, we are able to construct samples based on "mouse-articles" that were affected or unaffected by the NIH agreements. Second, both the timing and the scope of the NIH-MoU were effectively unanticipated by the mouse genetics community. As a result, there was an unexpected and dramatic shift in the level of openness in a short period of time. Finally, we are able to take advantage of detailed bibliometric data for articles citing the mouse-articles in either the treatment or control groups to characterize how the openness shock changed the nature of subsequent research (relative to the evolution of citations within the control group).

To implement this empirical approach, we analyze the citations to a sample of more than 2000 mouse-articles, approximately $10 \%$ of which described Crelox and Onco mice that experienced a shift in the level of openness as the result of the NIH agreements. By comparing citations to the mouse-articles before and after the agreement (and comparing them to the evolution of citations in the control sample), we are able to isolate the causal impact of a shift in scientific openness on the level and nature of follow-on research. In particular, rather than simply examine whether there is a net increase or decrease in the level of citations, the bulk of our analysis examines how the nature of citations differs after the openness shock. Specifically, we construct measures capturing whether there is a shift in the size of the research community using a particular mouse (i.e. the number of new authors citing the mouse-article), whether research is associated with the establishment of new research lines that had not previously used a particular mouse (i.e. whether the citations include keywords that had never been linked to particular mouse-mouse), and whether the research is basic and "upstream" or applied and "downstream" in nature (as captured by the journals in which the citations are published). Thus we develop three distinctive empirical tests that map to the three core claims of our theoretical framework.

Our results can be summarized as follows. First, the NIH agreements result in a significant increase in the level of follow-on research. More importantly, the bulk of the new citations arise from articles published by "new" researchers or institutions. In other words, most of the incremental citations to a given mouse-article come from researchers working at institutions that had not cited that mouse-article prior to the NIH agreement. Next, our results offer direct evidence that increased scientific openness is associated with the establishment of entirely new research lines. Specifically, the openness shocks lead to a significant increase in the diversity of the journals in which mouse-articles in the treatment group are cited, and, perhaps even more strikingly, a very significant increase in the number of previously unused "keywords" describing the underlying research contributions of the citing articles. Finally, Cre-Lox and Onco mice differed in terms of whether researchers had any access prior to the agreement (but faced some threat of IP enforcement) thus leading to differences in the likely impact of the NIH agreements. While the mice covered by the Onco agreement were available, researchers were responsible for separately signing licenses as they 
moved to downstream applications. Mice based on the Cre-Lox technology were much more limited in their distribution. Reflecting these differences (and our theoretical predictions), mouse-articles associated with the Cre-Lox agreement experience a significant increase in citations by basic research journals, while mouse-articles associated with the Onco agreement realize a citation increase in applied research journals. Taken together, this evidence is consistent with the view that the NIH agreement facilitated access to research inputs. As a result, in academic settings where control rights over research direction are in the hands of researchers, increased openness has at least as large an effect on enhancing the scope and diversity of horizontal exploration as it does on inducing vertical exploitation along well-defined research lines. This suggests that current debates over the relationship between IP and innovation should consider the impact of single IP rights over critical early-stage research tools as seriously as they have explored the implications of upstream IP thickets. Secondly, it suggests that our view of step-by-step innovation is strongly enhanced when we consider the multiplicity of both horizontal and vertical research lines.

The paper is organized as follows. Section 2 presents our theoretical framework and develops it main predictions concerning the effects of increased openness on the horizontal and vertical flow of research. Section 3 describes the experiment and the identification strategy. Section 4 presents the data and summary statistics. Section 5 presents the empirical results, and Section 6 concludes.

\section{Openness in scientific knowledge production}

We broadly define openness as any event or device that increases a researcher's ability to access the ideas or materials of other researchers. Alternatively, it allows researchers to provide access to her own ideas and share them as she sees fit. We shall argue that increased openness has three main effects on basic research. First, as noted in the introduction, openness tends to favor more applied research, possibly at the expense of more basic research, as it reduces the extent to which upstream researchers can appropriate the returns from their own research. Second, openness makes it easier for stage- $i$ researchers to "sell" their ideas to stage- $i+1$ researchers, leading to continuation of the research line; ex-ante, this encourages the upstream researchers to undertake stage $i$. Third, openness fosters more basic research and the creation of new lines, in particular by reducing researchers' cost of accessing other researchers' ideas, thereby making it more likely that the alternative strategies pursued by researchers with high levels of freedom will actually lead to new lines. We now discuss these various effects of openness, first abstracting from control rights considerations and focusing on the effects of openness on basic and applied research on a given line, then emphasizing the complementarity between openness and freedom and the resulting effect of openness on the diversity of lines. 


\subsection{Openness down a particular research line}

Consider a two-stage research line. Each stage requires one researcher. Success at each stage, occurs with probability $p$, and moves research up to the next stage. Then, as long as we focus on a single research line, a first effect of openness is that increases the extent to which stage 2 can extract rents from stage 1 . Thus, if $V$ denotes the ex post value of the line (e.g the price at which the research can be commercialized), then the value $\Pi_{2}$ of the line as of stage 2 , is equal to

$$
\Pi_{2}=p V+\psi-w,
$$

where $\psi$ is the additional rent openness gives stage 2 at the expense of stage 1 , and $w$ is the wage paid to a researcher (we take it as given for simplicity). The stage- 1 value of the line can then be expressed as:

$$
\Pi_{1}=p(p V-\psi-w)-w=p^{2} V-p \psi-(1+p) w .
$$

Thus, trivially, increasing $\psi$ fosters stage- 2 research at the expense of stage 1 research since it raises $\Pi_{2}$ and reduces $\Pi_{1}$.

Assume now that openness has an additional effect, by also increasing the possibility for the stage-1 researcher to transmit her research to stage 2 researcher(s). Indeed, once success has been obtained in stage 1, it may not be immediate to identify a researcher who will be able to carry the project forward into stage 2 . This may require a 'successful match', whose probability will naturally rise with openness. Specifically, we call the probability of such a match $A$ and we assume it depends positively on $\psi$. This means the stage- 1 value of the line becomes:

$$
\Pi_{1}=p A(\psi)(p V-\psi-w)-w=A(\psi)\left(p^{2} V-p \psi\right)-(1+p) w .
$$

In turn, this implies:

$$
\frac{d \Pi_{1}}{d \psi}=A^{\prime}(\psi)\left(p^{2} V-p \psi\right)-p A(\psi),
$$

which can be positive in particular if the effect of openness on the quality of matching is high (i.e. if $A^{\prime}(\psi)$ is high). ${ }^{2}$

To sum up, openness should be expected to foster downstream research thanks to higher appropriability. As for upstream research, the adverse effect of downstream appropriablility can at times be outweighed by a probability of finding a good match interested in pursuing the research agenda.

\subsection{Openness and diversification}

In this subsection we enrich the above framework by introducing the notion of academic freedom, drawing on Aghion, Dewatripont and Stein (2008), henceforth ADS. We then analyze the interplay between freedom and openness, and

\footnotetext{
${ }^{2}$ As long as we assume that research is socially optimal (i.e. if $p(p V-w)-w>0$ ), then a sufficient condition for openness to improve social welfare is that $\frac{d \Pi_{1}}{d \psi}>0$.
} 
in particular we argue that to the extent that early research stages are optimally managed under academic freedom, openness in early stages of research should foster the creation of new research lines.

\subsubsection{Introducing academic freedom: ADS}

We keep assuming that research proceeds along multi-stage lines, with each line starting with an initial idea $I_{0}$, and eventually generating a marketable product with value $V$ after $k \geq 2$ successful stages. As before, we assume that it is sufficient to hire one researcher per stage, and that this researcher obtains a probability of success equal to $p<1$ at any stage if he follows the success-maximizing ("practical") research strategy at that stage. But now we also assume that, instead of the practical strategy, a researcher is free to follow an "alternative" strategy. If we assume that the scientist has a zero individual probability of success following this approach, then this alternative strategy amounts to the scientist working on an activity that he enjoys more but that does not pay off in monetary terms. However, as we describe at the end of this section, we can interpret this alternative strategy as the case in which the scientist works on an activity that may help initiate new lines but does not generate progress on that particular line.

There is an infinite supply of researchers at each stage, each of whom has an outside option $w$. After being hired at stage $j$, the scientist is exposed to idea $I_{j-1}$, and then learns whether he would prefer following the practical strategy or the alternative strategy. If he is able to undertake his favored strategy, he suffers no disutility from working. If, however, the scientist has to undertake the strategy that he likes less, he suffers disutility of $z$. The ex ante probability that a scientist prefers to follow the practical strategy is given by $\alpha$. Assume further that the choice of the practical vs. alternative strategy is ex ante non-contractible. ${ }^{3}$

Academic research (or freedom) differs from private-sector research in that it leaves control rights over the research strategy in the hands of the researcher. Thus if a research line is pursued in academia, the researcher is paid wage $w$ and always works on his preferred strategy. This implies that with probability $\alpha$, the scientist works on the practical strategy, and with probability $(1-\alpha)$, he works on the alternative strategy. Thus the ex ante probability of advancing to the next stage is given by $\alpha p$. Now consider a researcher employed by the private sector. Whether the researcher prefers the practical or the alternative strategy, becomes evident once the researcher has been hired by the firm and has been given access to the idea by the firm owner. Yet ex post, the firm owner has the authority to force the scientist to work on the practical strategy. Anticipating this, the researcher will demand a wage of $w_{p}=w+(1-\alpha) z$ in order to work in the private sector. The $(1-\alpha) z$ markup over the academic wage represents

\footnotetext{
${ }^{3}$ In other words, one cannot write a contract that promises a scientist a bonus for following the practical strategy, because the nature of what kind of work that strategy entails cannot be adequately described ahead of time.
} 
compensation for loss of creative freedom-the fact that scientists now always have to adopt the practical strategy, whether this turns out to coincide with their preferences or not.

\subsubsection{When is freedom optimal?}

A main finding in ADS is that academic freedom tends to dominate private sector focus at earlier stages on a research line. To see this, take a research line involving 2 stages, and suppose that the first stage has been successful, so that we are now at stage 2 , with one more stage to be completed in order to generate a payoff of $V$. If this last stage of research is done in the private sector, the expected payoff is equal to $E\left(\pi_{2}^{p}\right)=p V-w_{p}$. If instead the last stage is done in academia, the expected payoff is equal to $E\left(\pi_{2}^{a}\right)=\alpha p V-w$. This means that private sector research will yield a higher payoff than free (academic) research and only if $(1-\alpha) p V>\left(w_{p}-w\right)$, or equivalently $p V>z$.

Now, let $\Pi_{2}$ denote the maximum of $E\left(\pi_{2}^{p}\right)$ and $E\left(\pi_{2}^{a}\right)$. Moving back to stage 1 , we now compare between $E\left(\pi_{1}^{p}\right)=p \Pi_{2}-w_{p}$ and $E\left(\pi_{1}^{a}\right)=\alpha p \Pi_{2}-w$. Private sector research will yield a higher payoff than free (academic) research at stage 1 if and only if $p \Pi_{2}>z$.

Since $\Pi_{2}<V$, it follows that private sector research is value-maximizing at stage 1 , it is also value-maximizing at stage 2 . In particular it cannot be value maximizing to have academic freedom operate at later stages than private sector research. The key result is therefore that academic freedom will be the optimal governance structure at earlier stages and private sector research will be optimal at later stages. The intuition is that while academia's wage cost advantage stays constant over research stages, its lower probability of success becomes more problematic as one approaches the final value $V$.

This result can be generalized to lines of any length $k:$ if $\Pi_{i}$ denotes the NPVs of the line of length $k$ as of stage $i$, we have:

$$
\Pi_{i}=\max \left\{E\left(\pi_{i}^{p}\right)=p \Pi_{i+1}-w_{p}, E\left(\pi_{i}^{a}\right)=\alpha p \Pi_{i+1}-w\right\}<\Pi_{i+1} .
$$

This monotonicity property, together with the fact that research should be pursued under academic freedom if and only if $p \Pi_{i+1}>z$, yields the desired result.

\subsubsection{The value of experimentation}

Note that the model so far provides a rationale for free (academic) research even in the extreme case where the alternative strategy has no value beyond saving the researcher the disutility of pursuing the practical strategy. In reality however there is value in experimenting with ideas that may lead to an entirely new research lines, consistently with the idea that scientific discoveries do not follow a purely "linear" model. This does not alter the relative optimality of academia (vs. private research) in earlier (vs. later) stages of research. It does, however, raise the desirability of freedom in general (and academia as the institutional regime that supports such freedom), if we make the realistic assumption that pursuing the alternative strategy confers a higher probability 
of generating entirely new research lines than pursuing the practical strategy (note that, realistically, the probability of such an event, possibly the result of an "accidental" discovery, is nonzero for both strategies $)^{4}$.

\subsubsection{Complementarity between openness and freedom: diversifica- tion effects}

That more openness should foster the creation of new lines, follows from the fact that openness favors the cross-fertilization of ideas within stages. More formally, consider two parallel research lines, 1 and 2, each of which operates as described above. Namely, with ex ante probability $\alpha$ the researcher initially allocated to the current stage of either of these two lines, prefers to pursue the practical strategy for that line whereas with probability $(1-\alpha)$ he prefers not to pursue this practical strategy. Now openness implies that the scientist on line 1 can learn about project 2 and vice-versa, and that consequently with positive probability $\varphi$, thanks to academic freedom and the resulting horizontal interaction, she may choose to work on the practical strategy for project 2 if nobody else does. A greater degree of openness implies a higher value of $\varphi$.

Openness also increases the net present value of a research line operated under academic freedom in a given stage $i$, from:

$$
\alpha p \Pi_{i}-w
$$

to:

$$
[\alpha+(1-\alpha) \varphi] p \Pi_{i}-w .
$$

Thus openness increased the social value of operating any stage (particularly earlier stages) under academic freedom.

The idea that openness favors cross-fertilization also implies that it should widen the pool of researchers and research institutions working on a particular research idea, since one key feature of academia is the fact that diverse researchers experiment with scientific ideas to investigate their full potential. What openness does is to reduce the fixed cost of 'entering' a particular research area to conduct these investigations.

Remark 1: An additional reason (see ADS), for why increased openness should foster free research and therefore the creation of new lines, is that one particular feature of academic institutions which help them enforce the commitment not to monitor individual scientists' research agenda, is that they typically are non-profit institutions. This in turn makes them less willing or less able to incur the cost of monitoring researchers. But that same feature also implies that a reduction in the cost of accessing research inputs, should make a bigger difference for academic research than for private sector research.

Remark 2: If openness enhances basic research and the creation of new lines, this implies that it should have a long-lasting effect on the flow of subsequent publications. This is because new lines take a significant amount of time before

\footnotetext{
${ }^{4}$ See ADS for details.
} 
maturing, and their development could lead to even more research lines being created. Indeed, starting a new line means a positive probability of a long dynamic flow of new discoveries whose research lines continue long after the original line has ended..

\subsection{Testable predictions}

Beyond the prediction that increasing the openness of critical early-stage research inputs should globally enhance the total flow of knowledge ${ }^{5}$, and the prediction that the causal impact of a shift to greater openness should be to generate more research over the long-run (not simply a short-run boost) ${ }^{6}$, the most important predictions from our model relate to the types of research and researchers most likely to be impacted by an "openness shock" in a world where researchers have control rights on their research activities. ${ }^{7}$ Three predictions stand out. First, an openness shock should increase the diversity of researchers engaged in follow-on innovation. With more open and independent access to innovation inputs, new researchers can overcome fixed cost barriers to move from other fields and build on these inputs. Second, an openness shock should increase the diversity in the types of research that are being pursued, as it fosters horizontal experimentation, therefore leading to the creation of new lines. Third, openness should have a different impact on basic or applied research. In particular when controls rights conditions are the first order consideration of the openness shift, then we would anticipate that the vertical exploitation outcome would dominate. However, when access costs are initially high or when control rights considerations are not first order, then we would expect the boost in openness to affect basic research with horizontal exploration dominating.

\section{Empirical setting: experiments in the open- ness of genetically engineered mice}

The remainder of this paper tests these ideas by taking advantage of two "natural experiments" that significantly shifted the level of openness associated with two broad categories of genetically engineered mice, both crucial inputs into cumulative research in the modern life sciences. ${ }^{8}$ To understand how we take

\footnotetext{
${ }^{5}$ This prediction is somewhat obvious and accords for example with a recent study estimating the significant and positive impact of Biological Resource Centers that make key research materials widely available to researchers (Furman \& Stern 2008).

${ }^{6}$ In other words, because the shift to greater openness is an enduring condition of key innovation inputs (under our model) and such inputs can be valuable to follow-on researchers over a long period - generating not one but multiple research lines - we would expect to see a long-run move to greater follow-on research, not simply a one time shock.

${ }^{7}$ In our particular empirical setting, the openness shock is focused directly and exclusively on academic (public-sector) researchers. We therefore do not make specific predictions regarding the overall balance of innovation between the public and the private sector.

${ }^{8}$ This section draws on Murray (2009) which offers an analytical narrative history of the role of intellectual property and openness in the mouse genetics community.
} 
advantage of these shifts in openness, it is useful to consider the essential role played by specialized research mice in modern life sciences research. With their genetic likeness to humans (the mouse and human genomes have a $99 \%$ similarity), mice play a central role in the study of cancer and other human diseases (Boguski, 2002). Throughout the twentieth century, scientists in mouse genetics relied on "spontaneous mutations" for their disease studies: researchers bred mice that naturally exhibited particular disease-linked symptoms or behaviors. ${ }^{9}$ To facilitate their efforts, the research community developed open access institutions, notably the Jackson Laboratory (a mouse repository in Bar Harbor, Maine) to classify, breed, and distribute specialized research mice to the academic community (referred to as "JAX" mice) (Rader 2004). In the early 1980s, advances in molecular biology and the ability to manipulate embryonic stem cells (Evans et al. 1984) allowed researchers to develop a set of systematic and precise methodologies for engineering specialized mice as research tools, greatly expanding the application of research mice in life sciences research (Ruddle et al. 1980, Brinster et al. 1981, Constantini \& Lacy 1981, Wagner et al. 1981ab). ${ }^{10}$ Three breakthroughs were particularly important. First, in a discovery awarded the 2007 Nobel Prize in Medicine, Mario Capecchi of the University of Utah and his collaborators developed "knock-out" technology, enabling researchers to delete specific genes in research mice (Doetschman et al. 1987; Thomas \& Capecchi 1987). Second, with partial funding from DuPont Corporation, Professor Phillip Leder at Harvard University developed Oncomouse methods, which provided a means for inserting (rather than deleting) genes into an embryo, thereby making mice susceptible to particular forms of cancer and other diseases (Stewart et al. 1984). Finally, researchers in the life sciences division of DuPont Corporation developed the Cre-Lox technology - a precise "cutting and pasting" tool that turns off genes in specific tissue or organs (Sauer et al. 1987).

By offering general-purpose tools to engineer discrete changes in the genetic profile of research mice, each of these three methods contributed to a paradigm shift in life sciences research. These tools gave scientists a means to investigate a wide variety of new research problems, from very basic research on the impact of genetic variation on disease incidence to the development and optimization of new therapies. ${ }^{11}$ In practical terms they allowed researchers to develop three

\footnotetext{
${ }^{9}$ Given the value of such mutations, researchers also developed techniques to significantly increase the rate of mutation of research mice such as the exposing pregnant mice to high levels of radiation (Green \& Roderick, 1966).

${ }^{10}$ The use of these methods for mouse engineering are complex and costly. To create a mouse with particular genes inserted within a mouse genome, scientists must first inject foreign DNA into mouse eggs, transplant the eggs into female mice, and, if successful, monitor and breed the incorporation of the genes into the offspring. During our sample period, the development of a "mouse line" from scratch likely involved at least 18 months of laboratory research and a significant investment of time and attention by a principal investigator (Rader 2004, Murray, 2009).

${ }^{11}$ The 2007 Nobel Prize announcement regarding knock-out mice states that "Almost every aspect of mammalian physiology can be studied by gene targeting. We have consequently witnessed an explosion of research activities applying the technology. Gene tar-
} 
different types of research mice: Knock-out, Cre-lox and Onco mice and to use these mice as critical research inputs in their experiments in addition to the more traditional spontaneous mice.

The revolution in mouse genetics occurred alongside several important shifts in the role of formal IP in life sciences research. In 1980, the Supreme Court decision in Diamond $v$ Chakrabarty established the patentability of genetically engineered organisms and the Bayh-Dole Act affirmatively allowed universities to seek patent protection and licensing revenues from Federally-funded research (Mowery et al 2004). ${ }^{12}$ By the mid-1990s, US universities receiving over 3,000 patents each year. While many observers took this as an indicator of universities' evolving role as engines of innovation and commercialization (Henderson, Jaffe \& Trajtenberg 1998), some argued that strong IP rights over scientific research discoveries were detrimental to research productivity and cumulative discovery (Heller \& Eisenberg 1998). In particular, some universities placed significant restrictions on the distribution of patented research materials to academic researchers (e.g., the University of Wisconsin restricted the open distribution and use of patented stem cell lines (see Murray 2007)) while other universities were accused of rent-seeking when they sought to enforce IP claims over independent commercial discoveries (e.g. the University of Rochester's enforcement of its patents on the Cox-2 pathway (Shane \& Somaya 2007).

Debates over the role of patents on scientific research tools were particularly salient for researchers exploiting the transformation in mouse genetics. All three of the key mouse engineering tools and the mice generated with them Knock-out mice, Oncomice and Cre-Lox mice - were covered under relatively broad patents. ${ }^{13}$ In the case of Knock-out mice, the University of Utah received a patent in 1987 but never sought to enforce the patent against follow-on researchers using the knock-out methodology. Instead, Knock-out mice were made available at (essentially) marginal cost through the Jackson Laboratory (i.e., these mice were distributed as JAX mice). The patents over the Onco and Cre-Lox technologies proved to be much more controversial. As a result of their partial funding of Harvard's Oncomouse discoveries and their internal development of Cre-Lox technology, DuPont gained exclusive control over patents for these two technologies. In contrast to the University of Utah, DuPont exercised strict control over the distribution and use of mice that exploited the techniques covered by their patent portfolio. During the early 1990s, researchers (and their institutions) who wanted "freedom to operate" were obliged to obtain a license from DuPont when they sought to receive and use an Onco or Cre-Lox mouse. The detailed licensing agreement required annual disclosure to DuPont regard-

geting has now been used by so many research groups and in so many contexts that it is impossible to make a brief summary of the results." (Nobel Prize Press Release http://nobelprize.org/nobel_prizes/medicine/laureates/2007/press.html).

${ }^{12}$ These legal and policy shifts reflected, in part, increasing appreciation that certain types of academic research were increasingly dual in nature: fundamental scientific discoveries that could simultaneously have a high degree of commercial utility (Stokes 1987; Murray \& Stern 2007)

${ }^{13}$ Knock-out mice were covered under U.S. Patent 4,687737, Oncomice under U.S. Patent 4,736,866 and Cre-lox mice under U.S. Patent 4959317. 
ing experimental progress, limits on informal mouse exchange among academic researchers, and "reach through" rights allowing DuPont to automatically receive licensing revenue from any commercial applications developed using either Cre-Lox or Onco technology.

These limits to openness caused widespread discontent among the academic community. Academic researchers objected to the exercise of patent rights by a for-profit company as a significant limitation on the norms of openness among academics, and claimed that the lack of access to these mice significantly reduced their freedom to pursue their own research agendas (Murray, 2009). ${ }^{14}$ Individual researchers engaged in various forms of protest - from attempt to initiate patent invalidation proceedings (which went nowhere) to informal sharing of mice (against the advice of their universities). As well, there were more systematic attempts to subvert or blunt the impact of the DuPont licensing regime: notably, in 1992 Dr. Ken Paigan, then director of JAX, announced he would make Onco-mice openly available without a license, directly contravening DuPont's IP rights. ${ }^{15}$ While some researchers took advantage of informal sharing or access of Onco-mice from the JAX (opening themselves to a potential infringement suit by DuPont), most researchers (and their institutions) were wary of the legal repercussions that could arise from using these mice, particularly for more applied research. Notably, through 1998, there was no access to Cre-Lox mice through an open-access depository such as JAX.

Thus, by the late 1990s, researchers seeking to use a particular specialized research mouse faced one of several access regimes. First, the most appropriate mouse for a particular research project might be a spontaneous mouse or a Knock-out mouse, and would (in general) be available on an open-access basis (from JAX or another provider) at marginal cost. ${ }^{16}$ Second, if the research required an Oncomouse, the mouse might be available informally through the peer-to-peer network or through JAX, but to use such a mouse (particularly for an applied project) was in direct contravention of DuPont's licensing requirements; it was also possible, in principle, to sign the DuPont licensing agreement, though very few institutions or researchers signed an actual agreement prior to 1999. Third, if a Cre-lox mouse was preferred, it might be available, but only through informal exchanges among colleagues. These informal exchanges were themselves beset by high transaction costs: Cre-lox developers invested considerable time and resources in its development and often required co-authorship (or other type of non-monetary payment) in exchange for access to their mice, and the exchange of such mice took place in the shadow of po-

\footnotetext{
${ }^{14}$ As cited in Murray 2009, DuPont's practices were seen as "an enormous obstacle to free and open distribution of information and materials....it was a whole new way of doing science. . it really affected the way the mouse research community works" (Rajewsky quoted in Jaffe 2004).

${ }^{15}$ Paigan Quote

${ }^{16}$ In addition to the unenforced Utah patent on knock-out technology, a small number of additional patents were granted over specialized knock-out mice. However, the intellectual property restrictions associated with these mice seems to have been negligible, and, in any case, their openness was not directly influenced by the NIH agreements that we exploit in our empirical work.
} 
tential infringement suits (which meant contravening the official policy rules of most universities) (Murray 2009). Finally, it was also feasible (at least in principle) to develop a new mouse as part of the research process, a process which could delay a project by at least 18 months and require significant resources and the development of specialized skills (and which could still be infringing on the DuPont patent portfolio).

The degree of openness associated with both Cre-Lox and Onco mice mice shifted dramatically in 1998 and 1999, respectively. In response to considerable pressure from the academic community throughout the 1990s, the National Institutes of Health (NIH), with the direct involvement of NIH Director and Nobel Laureate Harold Varmus, successfully negotiated two Memorandum of Understanding (MoU) among DuPont, the Jackson Laboratories (JAX), and the NIH. Together, they greatly increased the openness of genetically engineered mice for academic researchers. The Cre-Lox MoU, announced in July 1998, allowed JAX or universities to distribute and share Cre-lox mice with a simple license (essentially a standardized one-page material transfer agreement and an institution-wide license). In addition, JAX announced its commitment to acquire, breed, and distribute Cre-Lox mice on an open-access basis. A similar agreement for the Oncomouse was reached one year later (in July 1999), though the impact of this agreement was somewhat less dramatic as JAX had already been distributing Oncomice to researchers prior to the $1999 \mathrm{MoU}$.

Over a two-year period, life sciences researchers seeking to take advantage of the revolution in mouse genetics thus experienced a significant shift in their ability to access and exploit research mice covered under these agreements, while experiencing no shift in the degree of openness associated with either Knock-out or Spontaneous mice. These differences provide the key source of variation that we exploit in our empirical work. Three features are particularly useful to emphasize. First, while the "demand" for genetically engineered mice was increasing over time, there is no evidence that the potential demand for Onco or Cre-Lox mice was increasing at a faster (or slower) rate than the demand for Knock-out mice. Each technology represented a general purpose research tool, with the key distinction being that the Knock-out technology was made available on an open-access basis throughout the period, while the Onco and Cre-Lox technology faced significant open-access restrictions until the time of the NIH agreements. Second, though the academic community lobbied continuously for increased openness regarding these research tools, the timing of the agreement as well as its scope (essentially removing the main hurdles associated with access) were unanticipated (Marshall 1999). It is unlikely that researchers delayed projects in anticipation of such a comprehensive agreement; instead, researchers deterred by the DuPont licensing restrictions undertook different research projects or devoted themselves to other research directions (Murray 2009). Third, though the agreements cover two DuPont-controlled patents, they impacted a large number of different specialized research mice. In spite of the IP difficulties, by 1998, more than 50 different engineered mice had been developed and disclosed in the scientific literature using the Cre-Lox technology, and more than 160 different Oncomice were similarly described. As 
we outline in detail below, we can take advantage of the fact that these mice were developed and disclosed to the scientific literature at different times and that their follow-on use by other scientists is captured through the citation of these articles in follow-on scientific articles, to precisely identify the impact of the $\mathrm{NIH}$ openness agreements on the use of genetically engineered mice in follow-on scientific research.

Taken together, we believe that the openness shock associated with the NIH agreements accords well with the comparative statics developed in Section II. Specifically, engineered research mice are general purpose research tools that can be used in multiple research lines and at multiple research stages. Access restrictions on these research tools have the potential to significantly impact both the horizontal and vertical research incentives and productivity. On the one hand, DuPont's patent enforcement strategy is a strong candidate for vertical impact, as the threat of reach-through rights from DuPont limits the incentives to pursue more applied research stages. At the same time, the complicated and costly process of obtaining "freedom to operate" is also likely to reduce the degree of horizontal exploration. As predicted by our theory, the restrictions and transaction costs imposed by DuPont's enforcement choices would limit investment in early-stage academic research that depends upon these research tools but where it is also difficult to anticipate the precise research direction, requirements or outputs.

\section{Empirical strategy}

Our theoretical framework suggests that the level and nature of follow-on research depend not only upon the quality and type of research inputs available but also upon the degree of "openness" of these research inputs. To test this idea, we examine the impact of shifts in the openness of some engineered research mice (arising from the NIH agreements) on the level and type of followon research. Building on Furman and Stern (2008), this approach addresses a fundamental inference problem associated with traditional cross-sectional approaches to the evaluation of openness (and related institutional arrangements) on scientific research: If more "open" inputs are used more extensively by follow-on researchers, does this follow from the fact that they are open or from the fact that openness tends to be associated with higher-quality inputs and materials? In the absence of an empirical framework that disentangles selection effects (i.e., the correlation between openness and overall research impact) from the marginal impact of openness per se, we cannot construct the appropriate counterfactual estimate of the rate of follow-on research in the event that the same knowledge was available under a different level of openness.

Ideally, causal identification of the impact of openness would rely on a controlled experiment in which different knowledge inputs (such as particular research mice) were randomly allocated to distinct institutional environments with varying degrees of openness. A practical route towards capturing the essence of such an approach is to take advantage of natural institutional variations that 
shift key research inputs towards higher (or lower) levels of openness in a way that is exogenous both to their initial production and to their incorporation into follow-on research lines.

We implement this idea by taking advantage of the institutional changes to openness negotiated by the NIH that affected some (but not all) specialized research mice. ${ }^{17}$ As noted in the introduction, our empirical strategy exploits several distinctive elements of the system by which scientific research is disclosed and cited. First, in most cases, new specialized research mice are disclosed through publication in scientific articles that describe their production and distinctive characteristics (we refer to these disclosures as mouse-articles). Notably, we are able to identify mouse-articles both for mice affected by the NIH agreements (i.e., Cre-Lox and Onco mouse-articles) and for mice unaffected by the NIH agreements (i.e., Knock-Out and spontaneous mouse-articles). ${ }^{18}$ Second, we can trace out the impact of each mouse-article over time through the citations to that mouse-article by subsequent articles in the scientific literature. While an imperfect and noisy indicator of overall scientific impact, citations offer a systematic reflection of the process by which researchers acknowledge how their efforts at any one research stage build on the tools and knowledge developed by researchers in prior stages (Hagstrom, 1965; Merton 1973; de Solla Price, 1976; Garfield 1979; Cole 2000). More specifically, our approach exclusively examines the citation patterns associated with mouse-articles. Our qualitative research suggests that nearly all citations to mouse-articles involve the use of that specialized research mice in a follow-on experiment, and that most researchers routinely include a citation to the original mouse-article when a particular mouse is used in a follow-on project. Third, both the Cre-Lox and Onco NIH agreements occurred well after the publication dates of a large number of Cre-Lox and Onco mouse-articles; thus or each mouse-article we are able to observe citations both before and after the NIH agreement (and compare this to the pattern observed for our control groups which were unaffected by the NIH agreements). Finally, while there was pressure on the NIH and DuPont to move towards a more open regime, both the timing and extent of the openness shock are arguably exogenous. Specifically, the NIH agreement could have been reached, in principle, anytime from the early 1990s through the present. Moreover, our main control group - Knock-out mice - is likely to have been drawn from a sample of similar scientific quality/importance and differ only insofar as the patent over Knock-out technology was unenforced by the University of Utah.

Taken together, this empirical approach allows us to exploit the timing of

\footnotetext{
${ }^{17}$ Our approach builds on recent work applying a differences-in-differences econometric framework to analyze the institutional and microeconomic foundations of knowledge accumulation (Murray \& Stern, 2007, Furman \& Stern 2008, Huang \& Murray 2008, Rysman \& Simcoe 2008).

${ }^{18}$ While these types of mice differ in the precise details of the specialized genetic manipulation they allow, with the exception of Spontaneous mice, they are broadly similar in the scope of application and relevance to human disease. Moreover, all three were patented and could have been subject to strict enforcement. Spontaneous mice differ to the extent that they were not subject to patents.
} 
the openness shocks to observe pre- and post-shock citation rates to the treated mouse-articles (those associated with Cre-lox and Onco mice). By also including untreated mouse-articles (Knock-out and Spontaneous mice), we can more precisely identify a counterfactual estimate of the citation rate that would have occurred if the NIH agreement has not been signed. By measuring citations to Cre-lox and Onco mouse-articles before and after the openness shocks (and by measuring the citations to mouse-paper articles unaffected by the MoUs) we can separately identify the causal impact of both the Cre-lox and Onco openness agreements.

Our estimation approach uses an annual count of forward citations to a given mouse-article. As a starting point, we use a negative binomial to accommodate the fact that citation data comes in the form of skewed count data. Given the heterogeneity among scientific research articles, the nonlinear evolution of citations over time elapsed since initial publication, and the potential for differences over time in citation practices, we include article, article-age and calendar year fixed effects. To address the incidental parameters problem, we estimate a conditional fixed effects estimator (Hausman, Hall \& Griliches 1984). While the precise functional form will depend upon the precise test, it is useful to illustrate our overall approach by presenting the key estimation equations.

Our dependent variable is Citations $s_{j t}$ which measures the number of citations to a given mouse-article in a given calendar year. Our main specifications include an article fixed effect $\left(\gamma_{j}\right.$, which is conditioned out in estimation), year effects $\left(\beta_{t}\right)$ and article-age effects $\left(\delta_{t-P u b Y e a r}\right)$. We then include two measures to capture the impact of the NIH policy: OverallWindow and PostOverallShock. OverallWindow is a dummy variable equal to one for those mouse-articles impacted by a shock in the year of -and the year afterthe openness shock. ${ }^{19}$. PostOverallShock is the key treatment variable and is equal to one for mouse-articles impacted by the shock in citation-years after the window period (i.e after 1999 for Cre-Lox mouse-articles, and after 2000 for Oncomouse mouse-articles). Using a dataset composed of citations to mousearticles impacted by the shock and mouse-articles that are unaffected by the shock, our main specification for the impact of the NIH agreements on the level of citations is thus:

$$
\begin{aligned}
& \text { Citations }_{j t} \\
= & f\left(\varepsilon_{j t} ; \gamma_{j}+\beta_{t}+\delta_{t-\text { PubYear }}+\Psi_{0} \text { OverallWindow }_{j t}\right. \\
& \left.+\Psi_{1} \text { PostOverallShock }_{j t}\right),
\end{aligned}
$$

This specification tests for the impact of the NIH agreements by estimating how the citation rate for a mouse-article changes after it is impacted by one of the NIH agreements, accounting for fixed differences in the citation rate across articles and relative to the non-parametric trend in citation rates for the

\footnotetext{
${ }^{19}$ Consistent with our discussion in Section 3, the window period for the Cre-Lox period covers 1998 and 1999, and the window period for Oncomice covers 1999 and 2000.
} 
non-treated Knock-out and Spontaneous mouse-article control groups. This approach directly accounts for heterogeneity in the underlying quality of individual articles and the evolution of citations over time. ${ }^{20}$

We then build on this baseline specification to estimate the impact of openness on the nature and diversity of follow-on citations. To evaluate the impact of the openness shocks on different types of citations, we estimate the parameters from a two-equation system that divides Citations into two (mutually exclusive) types and estimates the effects of openness on each type. For example, a key prediction of the model is that openness is associated with an increase in the number of different researchers who utilize a given specialized research mouse. To test this hypothesis, we can contrast the impact of a shift in openness on follow-on publications by authors who have (or have not) cited a particular mouse-article before:

$$
\begin{aligned}
& \text { NewAuthorCitations } s_{j t} \\
= & f\left(\varepsilon_{j t} ; \gamma_{j}+\alpha_{N E W-O L D}+\beta_{t}+\delta_{t-P u b Y e a r}^{N E W}\right. \\
& +\Psi_{C R E_{0}}^{N E W} \text { CreLoxWindow } \\
& +\Psi_{\text {ONCO }}^{N E W} \text { OncoWindow }_{j t}+\Psi_{C R E_{1}}^{N E W} \text { PostCreLox Shock }_{j t} \text { PostOncoShock }_{j t},
\end{aligned}
$$

and

$$
\begin{aligned}
& \text { OldAuthorCitations }_{j t} \\
= & f\left(\varepsilon_{j t} ; \gamma_{j}+\beta_{t}+\delta_{t-P u b Y e a r}^{O L D}\right. \\
& +\Psi_{C R E_{0}}^{O L D} \text { CreLoxWindow } \\
& +\Psi_{\text {ONCO }}^{O L D} \text { OncoWindow }_{j t}+\Psi_{C R E_{1}}^{O L D D} \text { PostCre }_{\text {ONCO }} \text { PostOncoShock }_{j t},
\end{aligned}
$$

We impose some parametric restrictions due to data constraints, including setting the mouse-article fixed effects equal across both equations and allowing the calendar year fixed effects to differ by a fixed percentage. Notably, we allow for the publication age fixed effects to vary freely across both equations, as the evolution of citations in the time since publication will differ significantly for the two citation margins (in particular, most citations in the first few years after publication will be associated with "new" authors). Our hypothesis test focuses on whether $\Psi_{C R E_{1}}^{N E W}$ and $\Psi_{O N C O_{1}}^{N E W}$ are significantly larger than $\Psi_{C R E_{1}}^{O L D}$ and $\Psi_{O N C O_{1}}^{O L D}$, respectively. In other words, we evaluate whether the change in citations occurring after the openness shock arises due to a particular increase in

\footnotetext{
${ }^{20}$ It is also possible to separate out the treatment effect in several different ways. Our empirical work includes several specifications that estimate the impact of each NIH agreement separately by including separate window and treatment variables for the Cre-Lox shock and Oncomouse shocks. Also, we are able to evaluate the short-term versus long-term impact of the openness shocks by creating a measure a short-term treatment measure that captures the impact on citations during the first three years after the window period, and a separate longterm treatment measure that captures the permanent impact on citations for citation-years more than four years after the initial treatment.
} 
citations by authors who had not previously cited a particular mouse-article. We then develop similar specifications for several citation margins that capture the notion of diversity across research lines described in our theory: citations from new versus old institutions, using new versus old key words, and published in new versus old journals. Similarly, we explore the research response to the openness shocks along a given research line by comparing citations in applied versus basic journals.

In all our analyses, we provide in brackets the coefficients as incidence-rate ratios (a coefficient equal to one implies no effect on Citations $_{j t}$, whereas a coefficient equal to 1.50 implies a $50 \%$ boost to Citations $_{j t}$ ). All models also include and report block bootstrapped standard errors, clustered by mousearticle (MacKinnon, 2002).

\section{Empirical data}

\subsection{Data and sampling}

The data for this study are drawn from the entire population of research mice catalogued by the Mouse Genome Informatics (MGI) database. MGI consists of over 13,000 unique mice, thereby establishing a population of mouse-articles. Of this large population, we focus only on mouse-articles published between1992 and 1998 (the date of the first NIH agreement). As outlined above, we sample all mouse-articles for four types of mouse engineering technologies defined by MGI: Cre-lox, Onco, Knock-out and Spontaneous. In total, our sample includes 2638 novel mice linked to 2223 unique mouse-articles. The breakdown is as follows: 52 Cre-lox mice, 160 Onco mice, 2171 Knock-out mice, and 255 Spontaneous mice.

For all 2223 mouse-articles we obtain information on publication year from PubMed. We then used Thomson ISI Web of Science to collect all followon (forward) citations in academic journals for the year immediately following publication through to the end of 2006, to give a total of 525,865 citations. Each citation included detailed information on last author, reprint author, institutional addresses, key words, and journal characteristics (including name, impact factor and a basicness score). The citations were aggregated into 27,442 citation-year observations by combining all the citations received by a given mouse-article in any particular year as the basis for our analysis of the impact of the NIH agreement on the level of follow-on innovation.

To capture a variety of measures of the type of follow-on innovation, we code each of the citations according to a set of mutually exclusive categorical variables. Following our theoretical predictions, we focus on margins intended to capture horizontal experimentation across new lines. Our measures include the diversity of researchers in follow-on innovation - new researchers and new institutional affiliations, as well as the diversity of research - new key words and

new journals. To illustrate the construction of these variables, take the case of new key words. We consider a citation to include one or more new key words 
if the key word has never been used in citations to a particular mouse-article in any prior year. A citation is coded old in all other instances. This construction allows us to capture changes in the research landscape. Overall, we generate four new/old categorical variables:

i. New/Old Last Author: defined as new if the last author (listed in ISI Web of Science) has never appeared as a last author before in a citations to the mouse-article in prior years, old otherwise.

ii. New/Old Institution: defined as new if any address in the institution list has never appeared in an address list of citations to the mouse-article in prior years, old otherwise.

iii. New/Old Key Words: defined as new if a key word has never before appeared in the key word list of citations to the mouse-article, old otherwise.

iv. New/Old Journal: defined as new if the journal of the citation has never appeared before in the citations to the mouse-article, old otherwise.

We also categorize citations according to whether they are published in basic or applied journals following a schema developed by Lim (2000). This allows us to capture the predictions of our model regarding the impact of openness on the vertical direction of follow-on innovation i.e. whether these shifts lead to research further along particular research lines (towards commercialization). ${ }^{21}$ It is worth noting that in this analysis, multidisciplinary journals are classified as "basic" thus adding a conservative bias against finding an increase in basic research compared to applied research.

Taken together these measures allow us to explore the detailed predictions of our theory regarding the ways in which changes in openness impact the type of follow-on research along both horizontal and vertical dimensions. To do so, we implement the econometric approach laid out above and group the citations in each citation-year for any mouse-article into two mutually exclusive citation-year observations e.g. new key word citations and old key word citations, basic journal citations and applied journal citations etc. This gives us 54,884 citation-year observations and allows us to examine the impact of the NIH agreements on the two distinctive margins. As a result, we can investigate the hypothesis that changes in openness create more diverse lines of research, pursued by a more diverse range of scientists. We also investigate where along the research line (from basic to applied) the additional research is taking place. One caveat is worth noting: We do not examine the impact of openness on the academic/industry citation margin. One reason for this is that the openness shocks in our analysis are directed specifically to public-sector researchers. Further, for our entire sample we find that $97.5 \%$ of all forward citations have at least one of their authors in public institutions (of which $92.5 \%$ have only public-sector authors, and only $5 \%$ are public-private mix). With only $2.5 \%$ of citations having all private-sector authors, this margin is insignificant in the

\footnotetext{
${ }^{21}$ Our Basic/Applied Journal definition is based on work by Lim (2000) who used the measure building on a classification scheme developed by CHI Research, Inc. According to Lim, "CHI awards each journal a score from zero to four. For the biomedical sciences, they correspond to clinical observation, clinical mix, clinical investigation and basic science (see Hicks 1996, for more details)" (Lim 2000 p. 129).
} 
field of engineered mice.

\subsection{Variables and summary statistics}

Our empirical analysis measures follow-on innovation, as proxied by citations, to the 2223 mouse-articles in our sample. Table 1 provides variable names and definitions and Table 2 reports summary statistics for our data. Our mousearticles are published between 1992 and $1998($ mean $=1995)$ and have an average of seven authors. We trace citations to each mouse-article from the year after its publication until 2006 (with the mean of CitationYear ${ }_{j t}$ being 2001), giving us 27,442 citation-year observations. The mouse-articles receive a mean of 231 TotalCitations $s_{j}$. Our key dependent variable in the initial set of regressions is AnnualCitations $s_{j t}$ measuring the total number of citations to mouse-article $j$ in year $t$. The average number of annual citations for our mouse-articles is 18.32 (with a minimum of 0 and maximum of 336 citations received in any year). This is higher than the mean in other samples of life science papers (e.g. Murray \& Stern 2007), highlighting the importance of mouse genetics research in this period.

\section{TABLE 1 HERE}

TABLE 2 HERE

In our core analyses we break the annual citation count for any mouse-article into categorical margins of interest. As outlined above, to measure diversity of citing authors, we construct the two dependent variables: NewAuthorCitations $s_{j t}$ and OldAuthorCitations $s_{j t}$ by measuring number of citations by new (last) authors to article $j$ in year $t$; and the number of citations by old (last) authors to article $j$ in year $t$, respectively (mean $=11.0$ and 3.7 respectively). We then create an additional new/old dependent variable: NewInstitutionCitations $s_{j t}$ and OldInstitutionCitations $_{j t}$ (mean $=16.6$ and 9.7 respectively) to capture diversity at the institutional-level. Likewise, to capture diversity across research lines we code citations with new and old key words as NewKeywordCitations $s_{j t}$ and OldKeywordCitations $_{j t}$ (mean $=70.9$ and 52.3 respectively) as well as citations in new and old journals as NewJournalCitations $s_{j t}$ and OldJournalCitations $s_{j t}$ $($ mean $=7.5$ and 5.9 respectively $)$. Following a similar logic, and to capture vertical shifts in research along particular research lines, we define BasicCitations ${ }_{j t}$ and AppliedCitations ${ }_{j t}$, measuring the number of citations in basic journals to article $j$ in year $t$; and the number of forward citations in applied journals to article $j$ in year $t$, respectively (mean $=8.725$ and 6.947 respectively). ${ }^{22}$

\footnotetext{
${ }^{22}$ The sum of the annual means of our different margins do not add up to the mean annual citation count for several reasons. First, due to data-matching issues we are not always able to identify $100 \%$ of citations as belonging to one or the other margin; this leads to a sum lower than the mean annual citation count. Second, for the new/old margins, we focus on the count of unique instances of the characteristic in question; for example, if there are multiple citations from a particular journal to a mouse-article in a given year, we only count the first such citation. This also leads to margin citations to have a total mean lower than the annual citation rate. Finally, for the counts of institutions and keywords, each citation contains multiple entries for these fields, leading to counts higher than the mean annual citation count.
} 
As described in our empirical specification, we create three shock variables. The first is the PostOverallShock $k_{j t}$, equal to one if the article $j$ is subject to either of the two MoU openness shocks, and if the citation year is after the window period for the shock (mean $=0.0482$ ). The second and third variables capture the specific Cre and Onco shocks: PostCreLoxShock $k_{j t}$ is equal to one if the article $j$ is subject to the Cre-lox MoU openness shock, and if the citation year is after the Cre-lox window period for the shock $($ mean $=0.013)$ and PostOncoShock ${ }_{j t}$ equal to one if the article $j$ is subject to the Onco MoU openness shock, and if the citation year is after the OncoWindow period (2001 or later $)($ mean $=0.035)$.

TABLE 3 HERE

\section{Results}

Our empirical analysis estimates the causal impact of the openness shocks exemplified by the Memorandum of Understanding signed by DuPont, NIH and JAX dramatically opening up the access to Cre-lox (1998) and Onco (1999) mice for academic researchers. Recall that these agreements both reduced downstream expropriation of follow-on innovators (in the case of Cre-lox and Onco) by decreasing the reach-through rights available to DuPont, and increased access for follow-on innovators to the mice themselves (particularly in the case of Cre-lox mice). Our approach is to observe the annual citations to mouse-articles linked to Cre-lox and Onco mice in the pre- and post- shock period. By comparing the citation patterns to Knock-Out mice and Spontaneous mice unaffected by the MoUs and to the pre-shock trends for the treated mice, we can identify the impact of the shocks to openness.

Our analysis proceeds in several stages. First, we investigate the impact across both shocks on the overall flow of citations received by our mouse-articles. We also decompose the shocks to determine the specific impact of the Cre-lox and Onco shocks to better characterize their different causal impact. In both cases we also examine the time dynamics of the shocks. We then turn to the core of our analysis which first examines the Overall, Cre-lox and Onco shocks on the horizontal flow of research - by different researchers and across research lines and then the vertical flow of research along a given line (from basic to applied) . We capture the horizontal margin of "new" compared to "old" categories of citations, specifically key words, journals, authors, and institutions. In contrast, we use the vertical margin of basic versus applied journals to capture the downstream nature of research. By analyzing the impact of openness within the differences-in-differences framework, we are particularly interested in coefficient on the "shock" variable as this captures the change in citations (overall or for a particular margin) in the pre- and post-shock period. We focus on the IRR in our presentation because it is easily interpreted: it provides the multiplicative effect on the expected number of citations received with a one unit change in a regressor (i.e., the null hypothesis of no effect yields a coefficient of 1.0). For 
example an IRR of 1.25 on the shock variable can be interpreted as a $25 \%$ boost in citations in the post shock period.

\subsection{Impact of openness on the level of follow-on research}

Our regression results begin in Table 4 with a negative binomial specification using TotalCitations as the dependent variable. All specifications use the full set of fixed effects. Equation (4-1) column represents our baseline model, with the PostOverallShock variable. After accounting for the window period, we find that the coefficient on PostOverallShock is significant. On average, mousearticles affected by the shocks (Cre-lox and Onco mouse-articles) received an additional $21 \%$ increase in their annual citation rates after the MoUs are signed. The effect is identified both from the large set of control mouse-article papers and from the pre- and post- variations in article ages. Under specification (4-2) we divide the primary explanatory variable into PostOverallShock ${ }_{S}$ hortRun and PostOverallShock ${ }_{L}$ ongRun but make no other changes to the analysis. We find that the boost in overall citation rates is significant in both periods and is actually growing over time, with a $15 \%$ increase through 2003 and a $32 \%$ increase for 2004-2006. More than simply a lag in publishing after the initial PostOverallShock period (which is accounted for with the window variable), the significant and increasing boost in both periods represents a positive feedback effect, where the initial boost focuses greater attention on the lines of research affected by the shocks, resulting in even higher citation rates in the next round of scientific articles. In (4-3) we repeat these analysis but make separate estimates for the coefficients on the Cre-lox and Onco shocks - a specification that more accurately captures the differences in the two shocks (with respect to openness in the pre period). In (4-3), we show that the PostCreLoxShock variable is associated with a statistically significant (but noisy) increase of $18 \%$ in citations for Cre-lox mouse-articles compared to $21 \%$ for the PostOncoShock variable.

These results provide strong support for one key claim of this paper - that positive shocks to openness foster research intensity, rather than hindering it because of appropriability concerns surround critical research outputs. This adds support to previous empirical results, for example by Furman and Stern (2006), showing that the deposit of individual cell-lines (which provides openness through formal access) also increases follow-on innovation. In a complementary result, Murray and Stern (2007) find that limits on openness with the grant of intellectual property rights over knowledge have the converse effect; it decreases follow-on citations. Taken together, these results highlight the sensitivity of follow-on researchers to a variety of openness conditions, and provide increasing support for the perspective that these results are driven by researchers shifting their research choices rather than shifting their citations - it is hard to imagine the research community being so strategic in their citations that they increase and decrease their citations according to the precise timing and degree of openness shocks. Furthermore, our results on temporal dynamics are consistent with our theoretical setup, specifically the multi-staged view of innovation: if open- 
ness leads to more research activity and potentially to a branching out of new research lines (a conjecture we test in our next set of regressions) then these new lines would themselves generate follow-on research activity, amplifying over time the effects of any shocks to openness.

\section{TABLE 4 HERE}

To examine the impact of the openness shocks on the horizontal expansion of follow-on research, and to move to specifications that capture our core theoretical insight - that openness will have a more significant impact on new, early-stage research lines, where openness is complementary with freedom - we examine the impact of the openness shocks on several citation margins. As explained in the Estimated Equations section, we consider a series of two-equation systems that allows us to contrast various margins of the annual citations, helping to clarify the overall changes in behavior.

\subsection{Impact of openness on the type of follow-on research: horizontal exploration}

In Tables 5, 6 and 7, we present our analysis for the second main theoretical claim in our model predicting that greater openness will lead to greater horizontal experimentation, spawn a diverse array of new research lines and encourage the participation of new researchers who have previously not contributed to this arena of knowledge. We first present our evaluation of the impact of openness shocks on the diversity of researchers participating in follow-on research. Our key comparison is between researchers listed as the last author (the senior scientist) on citations who have never previously been listed on a citation to the mouse-article of interest, captured in our measure, NewAuthorCitations, and those previously listed in a citation to the particular mouse-article, measured by OldAuthorCitations. In the stacked regressions presented in (5-1a) and (5-1b) we estimate whether the marginal impact of the PostOverallShock is different for new versus old last-authors. When we separately evaluate the Cre-lox and Onco shocks on new and existing authors (5-2a) and (5-2b), we find that the Cre-lox openness shock leads to a $25 \%$ increase in new last-author citations, with no increase in old last-author citations. Similarly, the Onco shock leads to a $22 \%$ increase in new-author citations. Turning to the time dynamics for the overall shock (5-2a and 5-2b), in the short run we find an $18.5 \%$ increase in citations by new authors, compared to statistically insignificant increase in citations by old authors (with the difference of the coefficients significant at the $1 \%$ level); the results are $36 \%$ versus $21 \%$ for new versus old authors in the long-run. ${ }^{23}$ This provides strong evidence for the hypothesis that an increase

\footnotetext{
${ }^{23}$ We have experimented extensively with examining coefficients on a year-by-year basis relative to the time of the shock, in order to test for the presence of a pre-shock trend in either of the treatment groups (relative to controls) and to examine the evolution of each citation margin after the shock. While the pre-deposit trend is not statistically significant for any of the citation margins that we study, it is also true that these year-by-year coefficients
} 
in openness leads to new lines of research, as the shocks led to new authors focusing on the field.

In the final set of specifications in Table 5 (5-4a and 5-4b), we turn to an alternative measure of the diversity captured by the institutional affiliation. In this case institutions are coded from the address field of the particular mouse-article citation. This is particularly informative because it allows us to explore the micro-foundations of openness and mouse exchange at the institutional level. If researchers within a given institution (e.g. Northwestern University) share mice freely with one another once one of their colleagues has made the investment in accessing a mouse (or engineering one) then we would expect the surge in new authors to come predominantly from new institutions. Furthermore, any university-level agreement made prior to the $\mathrm{MoU}$ made follow-on research possible for all scientists within the university. As throughout Table 5, we used stacked regressions to estimate specifications comparing NewInstitutionCitations and OldInstitutionCitations. Comparing (5$4 \mathrm{a})$ and (5-4b), the impact of the overall openness shock increases citations from new institutions by $20 \%$ compared to $14 \%$ from old (existing) institutions. In other words, while the effect is less dramatic than the increased diversity of authors, the boost in marginal citations does accrue (significantly) to authors affiliated with new institutions.

\section{TABLE 5 HERE}

While our theoretical predictions highlight the importance of openness on reducing the fixed cost of critical upstream inputs into research projects, another important aspect of openness is the degree to which it facilitates horizontal experimentation by researchers now free to match with a variety of ideas, particularly given the conditions of freedom existing in the academic sector that we examine here. We capture this horizontal diversity using the measure of key words represented in a particular citation. Recall that these key words are defined by the cataloguing service (ISI Web of Science) and therefore not subject of strategic intervention by researchers themselves. We compare the citation margin between NewKeywordCitations and OldKeywordCitations in (6-1a) and (6-1b) finding that the PostOverallShock is $25 \%$ for new key words and and insignificant for old key words. This confirms our prediction that openness does indeed have a substantial impact on the diversity of new research lines. When we include the time dynamics (6-2a) and (6-2b) we find that the short run PostOverallShock effect on new key words is $20 \%$, and increases to $35 \%$ in the long run (both are significant at the $1 \%$ level). The old key word impact is insignificant. Taken together these provide strong evidence for expanding research lines. When we decompose the openness shock into the Crelox and Onco shocks, the results are also dramatic. The PostCreLoxShock is $30 \%$ while the

are imprecisely estimated, in part because of the relatively small number of annual citationyear observations in the treatment groups. Instead, we estimate two coefficients for each citation margin to evaluate the short-term versus long-term effects of the openness shifts, which reinforce the idea that the impact of the policy had a larger impact after a period of adjustment. 
Onco shock is only $20 \%$ (significant at the $5 \%$ and $10 \%$ level respectively) suggesting that it is the Cre-lox shock that has the most salient impact on the initiation of diverse early-stage lines. Neither the Cre-lox nor the Onco Shocks have a significant impact on old key words.

\section{TABLE 6 HERE}

Our final investigation to establish the impact of openness on diversity is the emergence of research lines focusing on new areas of scientific study captured in journals. As a proxy for this breadth of research, we compare the citation margin between NewJournalCitations and OldJournalCitations, where a "new" journal is one which has never before published an article citing the original mouse-paper article in question. In Table 7, we see that the PostOverallShock in (7-1a) and (7-1b) leads to a $24 \%$ increase (significant at the $1 \%$ level) in citations from new journals, and no significant increase in citations from old journals. We further investigate the impact of openness in (7-2a) and (7-2b) which show that the short run effect is $22 \%$ for new journals increasing to $27 \%$ in the long run, while there is no short run impact for old journals, but the long run PostOverallShock is $23 \%$. Finally, in (7-3a) and (7-3b) we examine the Cre and Onco shocks, finding that the Cre-lox shock has an impact on NewJournalCitations of $24 \%$ but the effect is noisy and only significant at the $15 \%$ level, however, the Onco shock is leads to a $24 \%$ increase to citations in new journals with no significant increase in citations in old journals (significant at the $1 \%$ level). As with our analysis of key words, the pattern of citations to new and old journals indicates that the increase in openness leads to a greater diversity of research topics stemming from the affected mouse-articles. This supports our theoretical prediction of greater horizontal experimentation as researchers have greater access to the inputs of upstream research.

\section{TABLE 7 HERE}

\subsection{Impact of openness on the type of follow-on research: vertical exploitation}

We now turn to the effects of openness shocks on the vertical distribution of research, in other words, whether openness shocks move research along any particular line towards later stage projects. We do this by examining the marginal impact of the openness shocks on the production of research in basic versus applied research journals. Recall that these categories are determined by examining the journal in which citations are published, categorized according to how close to clinical application the work typically published (across the entire stock of articles published in the journal over a five year time period). In (8-1a) and (81b), we find that the BasicCitations dependent variable increases $23 \%$ during the post-shock period; at the same time, the AppliedCitations variable experiences $18 \%$ increase during the post-shock period. This suggests that across both shocks, the average impact accrues to both basic and applied citations. In 
our next regressions, however, we provide deeper insights into these patterns by again considering the contrasting natures of the Cre-lox and Onco shocks and disentangling their distinctive implications. Recall that in the pre-shock period, not only were there stringent reach-through rights associated with Cre-lox mice, but also very limited access as ex ante enforcement of IP rights had limited their circulation and exchange. In contrast, Onco mice were made available through JAX - although these researchers remained concerned that if they found interesting commercial applications they may be subject to ex post IP enforcement. As a result, the Onco shock also reduced reach-through rights but had a more limited impact on access. The specifications in (8-2a) and (8-2b) reveal that the Cre-lox shock is concentrated in basic citations, while the Onco shock has a significant effect only on applied citations. Specifically, the Cre-lox shock leads to a dramatic $78 \%$ increase in basic citations during the post-shock period, but has a $21 \%$ decrease on the applied-research citation flows (significant at the $10 \%$ level). By contrast, the impact of the Onco shock is concentrated in the more applied research stages and leads to a $56 \%$ increase during the period through 2006 for applied citations; at the same time, the Onco shock has no significant impact on basic citations. This is consistent with the view that when upstream access is already secured (as in the case for Onco mice), then an agreement that shifts the balance of appropriability toward follow-on innovators and away from the initial innovator (DuPont), then there is more applied research.

\section{TABLE 8 HERE}

These results are further reinforced when we look at the time dynamics (8$3 a)$ and (8-3b). In this case, rather than look at the time dynamics for the overall shock, we examine the time dynamics for the Cre-lox and Onco shocks separately. We find that the Cre-lox shock has a $63 \%$ increase in basic citations in the short run and a dramatic $114 \%$ increase over the next three years (through 2006). There is a significant negative impact on applied citations in the short run $(-25 \%)$ but no change in the long run. While we might have anticipated that there would be a gradual shift to applied research in the long run, this suggests that the early stages of the Cre-lox research lines take time and that applications are relatively far away. Conversely, in the Onco case, the shock to citations is entirely concentrated in applied research with a $51 \%$ boost in the short run and $63 \%$ in the long run.

Taken together, our findings suggest that both the Cre-lox and Onco shocks had an important impact on the rate and nature of follow-on innovation. Of course our interpretation depends upon the extent to which the MoU shocks to openness were truly exogenous. After all, they reflected the endogenous choice of DuPont, JAX, and the NIH. There is, however, strong evidence to suggest that the Cre-lox shock and (to a lesser extent) the Onco shock were unanticipated in their timing and terms by the scientific community and that while the academic community had agitated for broader access, this had been a continuous request starting in the early 1990s, rather than a significant sea change in response to changing technical opportunities (Murray, 2008). Moreover, our focus is on 
the behavioral (citation) response of over 5,000 follow-on researchers who were not part of the intense, but largely private, negotiations. More than simply a policy announcement, or even an agreement that ratified behavior already taking place, the MoUs directly and dramatically changed the openness of a set of key research inputs.

\section{Conclusion}

In this paper we argued that openness of upstream research does not simply encourage higher levels of downstream exploitation: it also raises the incentives for additional upstream research by encouraging the establishment of entirely new research directions. We tested this hypothesis by examining a "natural experiment" in openness within the academic community: NIH agreements during the late 1990s that circumscribed IP restrictions for academics regarding certain genetically engineered mice.

First, we found, not surprisingly, that there is an increased overall level of follow-on research taking place after the NIH-DuPont-JAX openness agreements. Building on this initial result, we explored the particular margins where this increased innovation is taking place, developing measures of innovation that allowed us to test the predictions of our theory. First, we obtained robust evidence that increased openness was associated with the exploration of a wider range of more diverse research paths, which in turn reflects an increase in horizontal experimentation. This finding highlights a feature of early stage knowledge overlooked in many of the current models of innovation - the fact that it is non-rivalrous and as a consequence, can, in principle, be applied across multiple later-stage domains and applications. Second, when we compared the impact of openness on horizontal exploration versus vertical exploitation we found that on balance, when pre-existing IP restrictions limited access to research materials (rather than simply serve as a threat of potential future enforcement), the main impact of openness was an increase in more basic and more high-quality follow-on research publications. In contrast, when prior arrangements (informal or formal) had allowed for access even with some threat of enforcement, the openness shock would mainly affect the more applied follow-on research.

Our results highlight that the current literature on intellectual property and innovation has neglected a key potential cost of intellectual property - the limits that IP rights may place on the diversity of research that would otherwise be pursued by follow-on innovators taking a single powerful idea and experimenting across multiple research lines.

Our research in this paper could be extended in several interesting directions. A first avenue would be to reassess the Bayh-Dole Act in light of our analysis. Indeed our results highlight one of the possible dangers of excessive IP enforcement: if IP is used to restrict openness particularly at very early stages of the research line, then it is possible that the rich array of exploration projects that are key to diverse follow-on innovation will be stifled.

Second, our framework suggests that more attention be paid by economists 
to recent attempts by the corporate sector to generate new sources of profit built on the openness of knowledge production by others (Huang \& Murray 2008). Thus, Tapscott and Williams (2006) explain how IBM has managed to recover from competition with Microsoft by engaging in the openness promoted by Linux. More generally, a systematic analysis of the forces and trade-offs at work in an economic environment with both proprietary and open firms competing with each other, awaits future research.

\section{References}

[1] Aghion, P, Dewatripont, M, and Stein, J (2008), "Academic Freedom and Private Sector Focus", mimeo, Harvard, forthcoming, Rand Journal of Economics.

[2] Arrow, K (1962), "Economics of Welfare and the Allocation of Resources for Invention", in R. Nelson ed., The Rate and Direction of Inventive Activity, Princeton University Press.

[3] Anderson, Christopher. 1993. "Researchers win decision on knockout mouse pricing". Science, Vol. 260 (5104), pp. 23-24.

[4] Azoulay, Pierre, Waverly Ding, and Toby Stuart. 2007. "The Impact of Academic Patenting on (Public) Research Output. Journal of Economic Behavior and Organization 63, no. 4, pp. 599-623.

[5] Boguski, Mark S. 2002. "Comparative genomics: the mouse that roared." Nature 420(6915): 515-6.

[6] Bresnahan, Timothy F. \& Trajtenberg, M., 1995. "General purpose technologies 'Engines of growth'?," Journal of Econometrics, Vol. 65(1), pages 83-108

[7] Brinster, Ralph L., H. Y. Chen, M. Trumbauer, A. W. Senear, and R. Warren et al. 1981. Somatic expression of herpes thymidine kinase in mice following injection of a fusion gene into eggs. Cell 27:223-231.

[8] Brinster, Ralph L., H.Y. Chen, A. Messing, T. Vandyke, A.J. Levine and R.D. Palmiter. 1984. "Transgenic Mice Harboring SV40 T-Antigen Genes Develop Characteristic Brain-tumors. Cell 37 (2): 367-379.

[9] Constantini, Frank and E. Lacy, 1981. "Introduction of a rabbit beta-globin gene into the mouse germ line". Nature 294:92-94.

[10] Dasgupta, Partha and David, Paul. 1994. "Towards a New Economics of Science" Research Policy (23), 487-521.

[11] David, Paul. 2001a. "From Keeping 'Nature's Secrets' to the Institutionalization of 'Open Science" Stanford Working Paper \#01-006. 
[12] David, Paul. 2001b. "Will Building Good Fences really make Good Neighbors in Science" Stanford Working Paper \#01-005.

[13] de Solla Price, D. J. 1965. Networks of scientific papers. Science. 149(3683) 510-515.

[14] Ding, Waverly, Fiona Murray, and Toby Stuart. 2006. "Gender Differences in Patenting in the Academic Life Sciences." Science, Vol. 313 (5787), p.665667.

[15] Dreyfuss, Rochelle. 2004. "Protecting the Public Domain of Science: Has the Time for an Experimental Use Defense Arrived?" 46 Arizona Law Review p.457.

[16] Fauchart, E. E. Von Hippel. 2007. Norms-Based Intellectual Property Systems: The Case of French Chefs. Organization Science.

[17] Furman, J., S. Stern. 2006. Climbing atop the shoulders of giants: The impact of institutions on cumulative research. Working paper, National Bureau of Economic Research, Cambridge, MA.

[18] Garfield, E. 1979. Citation Indexing. Philadelphia, PA: ISI.

[19] Gordon, J. W., G. A. Scangos, D. J. Plotkin, J. A. Barbosa, and F. H. Ruddle, 1980. "Genetic transformation of mouse embryos by microinjection of purified DNA". Proc. Natl. Acad. Sci. USA 77:7380-7384.

[20] Hagström, Warren O. 1965. The scientific community. New York: Basic Books.

[21] Hall, B. H., A. B. Jaffe, M. Trajtenberg,. 2001. The NBER patent citation data file: Lessons, insights and methodological tools. Working paper no. 8498, NBER, Cambridge, MA.

[22] Heller, Michael. 2008. Gridlock Economy: How too much ownership wrecks markets, stops innovation and costs lives. Philadelphia PA: Basic Books.

[23] Heller, M, and Eisenberg, R (1998), "Can Patents Deter Innovation? The Anticommons in Biomedical Research", Science, 280, 698-701.

[24] Henderson, R, Jaffe, A, and Trajtenberg, M (1998), "Universities as a Source of Commercial Technology: A Detailed Analysis of University Patenting, 1965-1988", Review of Economics and Statistics, 80, 119-127.

[25] Howitt, P (2003), "The Economics of Science and the Future of Universities", The Timlin Lecture 2000, University of Saskatchewan.

[26] Huang, Kenneth, F. Murray. 2008. Does Patent Strategy Shape The LongRun Supply Of Public Knowledge? Evidence From The Human Genome. Forthcoming in Academy of Management Journal. 
[27] Marshall, Eliot. 1999. "New NIH Rules Promote Greater Sharing of Tools and Materials". Science, Vol. 286(5449), pp. 2430-2431.

[28] Marshall, Eliot. 2000. "NIH Cuts Deal on Use of Oncomouse". Science, Vol. 287(5453), p. 567.

[29] Marshall, Eliot. 2002. "DuPont Ups Ante on Use of Harvard's Oncomouse". Science, Vol. 296, pp. 1212-1213.

[30] Merton, Robert. 1973. The Sociology of Science: Theoretical and Empirical Investigations. Edited by Norman Storer. Chicago: University of Chicago Press.

[31] Mokyr, Joel. 2002. The Gifts of Athena: Historical Origins of the Knowledge Economy. Princeton: Princeton University Press.

[32] Mowery, David, Richard Nelson, Bhaven Sampat, and Arvids Ziedonis. 2001. "The Growth of Patenting and Licensing by U.S. Universities: An Assessment of the Effects of the Bayh-Dole Act of 1980." Research Policy 30:99-119.

[33] Murray, Fiona and Scott Stern. 2007. "Do Formal Intellectual Property Rights Hinder the Free Flow of Scientific Knowledge? An Empirical Test of the anti-Commons Hypothesis," Journal of Economic Behavior and Organization, Vol. 63:4, pp. 648-687.

[34] Murray, Fiona. 2002. "Innovation as co-evolution of scientific and technological networks: exploring tissue engineering". Research Policy, Vol. 31, Issues 8-9, pp: 1389-1403.

[35] Murray, Fiona. 2007. "The Stem Cell Market: Patents \& the Pursuit of Scientific Progress." New England Journal of Medicine, Vol. 356:23, pp. 2341-2343.

[36] Murray, Fiona. 2008. The Oncomouse that Roared: Hybrid Exchange Strategies As A Source Of Productive Tension At The Boundary Of Overlapping Institutions. Forthcoming American Journal of Sociology and Working Paper, Sloan School of Management.

[37] Nelson, Richard R. 1959. "The Simple Economics of Basic Scientific Research," Journal of Political Economy 67(3), 297-306.

[38] O’Mahony, S. 2003. "Guarding the Commons: How Community Managed Projects Protect Their Work", Research Policy: 32, 1179-1198.

[39] Oliar, D., C. Sprigman. 2008. Intellectual Property Norms Among StandUp Comedians, Va. L. Rev.

[40] Owen-Smith, Jason, and Walter W. Powell. 2003. "The Expanding Role of University Patenting in the Life Sciences: Assessing the Importance of Experience and Connectivity." Research Policy 32(9): 1695-1711. 
[41] Paigen, Ken. 2003. One Hundred Years of Mouse Genetics: An Intellectual History. I. The Classical Period (1902-1980). Genetics 2003 163: 1-7.

[42] Rader, Karen. 2004. Making Mice. Princeton, NJ: Princeton University Press.

[43] Russell, E. S. (1978). "Origins and history of mouse inbred strains: contributions of Clarence Cook Little". In Origins of Inbred Mice, Morse, H. C., eds. (Academic Press, NY), pp. 33-43.

[44] Rysman, M., \& Simcoe, T. S. 2008. Patents and the performance of voluntary standard setting organizations. Forthcoming Management Science and Working Paper No. 05-22, NET Institute. Available at SSRN: http://ssrn.com/abstract $=851245$.

[45] Scotchmer, S. 1991. "Standing on the Shoulders of Giants: Cumulative Research and the Patent Law", Journal of Economic Perspectives 5, 2941.

[46] Scotchmer, Suzanne. 1996. "Protecting Early Innovators: Should SecondGeneration Products be Patentable?" The Rand Journal of Economics 27, Summer 1996, 322-331.

[47] Stern, S (2004), "Do Scientists Pay to Be Scientists", Management Science.

[48] Stewart, Timothy A., Paul K. Pattengale, and Philip Leder. 1984. "Spontaneous Mammary Adenocarcinomas in Transgenic Mice That Carry and Express MTV/myc Fusion Genes". Cell 38: 627-637.

[49] Strong, Lionel C. 1978. Inbred mice in science. In Origins of Inbred Mice, Morse, H. C., eds. (Academic Press, New York), pp. 45-67.

[50] Wagner, E. F., Stewart, Timothy A., and Beatrice Mintz. 1981. "The human beta-globin gene and a functional viral thymidine kinase gene in developing mice." Proc Natl Acad Sci 78, 5016-20.

[51] Wagner, T.E., P. C. Hoppe, J.D. Jollick, D.R. Scholl, R.L. Hokinka et al., 1981 Microinjection of a rabbit beta-globin gene into zygotes and its subsequent expression in adult mice and their offspring. Proc. Natl. Acad. Sci. 78:6376-6380.

[52] Walsh, John, Ashish Arora, and Wesley Cohen. 2003. "Science and the Law: Working Through the Patent Problem." Science, Vol 299, Issue 5609, 1021, 14 February 2003

[53] Walsh, John, Charlene Cho, and Wesley Cohen. 2005. "View from the Bench: Patents and Material Transfers." Science, Vol. 309, Issue 5743, 23 September 2005. 


\section{TABLE 1: VARIABLES \& DEFINITIONS}

\begin{tabular}{|c|c|c|}
\hline VARIABLE & DEFINITION & SOURCE \\
\hline \multicolumn{3}{|c|}{ PUBLICATION CHARACTERISTICS } \\
\hline Publication Yearj & Year in which article $j$ is published & PM \\
\hline \# Authorsj & Count of the number of authors of Article $j$ & PM \\
\hline Total Citationsj & \# of FORWARD CITATIONS from publication date through 2006 & SCI \\
\hline \multicolumn{3}{|c|}{ CITATION-YEAR CHARACTERISTICS } \\
\hline Annual Citations & \# of Forward Citations to Article $j$ in Year $t$ & SCI \\
\hline Citation Yearjt & Year in which FORWARD CITATIONS are received & SCI \\
\hline \multicolumn{3}{|c|}{ CITATION CHARACTERISTICS } \\
\hline New Author Citation & $\begin{array}{l}\text { Dummy variable equal to } 1 \text { if the last author has not appeared in the citations } \\
\text { to the mouse-article in prior years; } 0 \text { otherwise }\end{array}$ & PM \\
\hline Old Author Citation & $\begin{array}{l}\text { Dummy variable equal to } 1 \text { if the last author has appeared in the citations to } \\
\text { the mouse-article in prior years; } 0 \text { otherwise }\end{array}$ & PM \\
\hline New Institution Citation & $\begin{array}{l}\text { Dummy variable equal to } 1 \text { if the institutional affiliation has not appeared in } \\
\text { the citations to the mouse-article in prior years; } 0 \text { otherwise }\end{array}$ & $\mathrm{PM}$ \\
\hline Old Institution Citation & $\begin{array}{l}\text { Dummy variable equal to } 1 \text { if the institutional affiliation has not appeared in } \\
\text { the citations to the mouse-article in prior years; } 0 \text { otherwise }\end{array}$ & PM \\
\hline New Key Word Citation & $\begin{array}{l}\text { Dummy variable equal to } 1 \text { if the key word has not appeared in the citations to } \\
\text { the mouse-article in prior years; } 0 \text { otherwise }\end{array}$ & PM \\
\hline Old Key Word Citation & $\begin{array}{l}\text { Dummy variable equal to } 1 \text { if the key word has appeared in the citations to the } \\
\text { mouse-article in prior years; } 0 \text { otherwise }\end{array}$ & PM \\
\hline New Journal Citation & $\begin{array}{l}\text { Dummy variable equal to } 1 \text { if the publishing journal has not appeared in the } \\
\text { citations to the mouse-article in prior years; } 0 \text { otherwise }\end{array}$ & PM \\
\hline Old Journal Citation & $\begin{array}{l}\text { Dummy variable equal to } 1 \text { if the publishing journal has appeared in the } \\
\text { citations to the mouse-article in prior years; } 0 \text { otherwise }\end{array}$ & PM \\
\hline Basic Citation & $\begin{array}{l}\text { Dummy variable equal to } 1 \text { if the publishing journal is identified as a basic- } \\
\text { research journal (SOURCE: CHIBasic variable); } 0 \text { otherwise }\end{array}$ & PM \\
\hline Applied Citation & $\begin{array}{l}\text { Dummy variable equal to } 1 \text { if the publishing journal is identified as an applied- } \\
\text { research journal (SOURCE: CHIBasic variable); } 0 \text { otherwise }\end{array}$ & PM \\
\hline At Least One Public Author & $\begin{array}{l}\text { Dummy variable equal to } 1 \text { if at least one institutional affiliation associated } \\
\text { with the citing article is a university or government organization; } 0 \text { otherwise }\end{array}$ & PM \\
\hline Private Author & $\begin{array}{l}\text { Dummy variable equal to } 1 \text { if all institutional affiliations associated with the } \\
\text { citing article is a biotechnology or pharmaceutical firm; } 0 \text { otherwise }\end{array}$ & PM \\
\hline \multicolumn{3}{|c|}{ OPENNESS SHOCK CHARACTERISTICS } \\
\hline Post Overall Shockjt & $\begin{array}{l}\text { Dummy variable equal to } 1 \text { if Article } j \text { is associated with an openness MOU } \\
\text { agreement (Cre-Lox, Onco) which is in effect in year } t \text {. }\end{array}$ & MGI \\
\hline Post Overall Windowjt & $\begin{array}{l}\text { Dummy variable equal to } 1 \text { if Article } j \text { is associated with an openness MoU } \\
\text { agreement (Cre-Lox, Onco) which is in its initial period in year } t \text {. }\end{array}$ & MGI \\
\hline Post Crelox Shockjt & $\begin{array}{l}\text { Dummy variable equal to } 1 \text { if Article } j \text { is associated with the Cre-Lox openness } \\
\text { MoU and that agreement is in effect in year } t \text {. }\end{array}$ & MGI \\
\hline Post Crelox Windowjt & $\begin{array}{l}\text { Dummy variable equal to } 1 \text { if Article } j \text { is associated with the Cre-Lox openness } \\
\text { MoU and that agreement is in its initial period in year } t \text {. }\end{array}$ & MGI \\
\hline Post Onco Shockjt & $\begin{array}{l}\text { Dummy variable equal to } 1 \text { if Article } j \text { is associated with the Onco openness } \\
\text { MoU and that agreement is in effect in year } t \text {. }\end{array}$ & MGI \\
\hline Post Onco Windowjt & $\begin{array}{l}\text { Dummy variable equal to } 1 \text { if Article } j \text { is associated with the Onco openness } \\
\text { MoU and that agreement is in effect in year } t \text {. }\end{array}$ & MGI \\
\hline
\end{tabular}


TABLE 2: MEANS \& STANDARD DEVIATIONS

\begin{tabular}{|c|c|c|c|c|c|}
\hline VARIABLE & $\mathbf{N}$ & MEAN & STD. DEV. & MIN & MAX \\
\hline \multicolumn{6}{|c|}{ PUBLICATION CHARACTERISTICS ( $N=2,223$ original publication) } \\
\hline Publication Yearj & 2223 & 1995.35 & 2.83 & 1983 & 1998 \\
\hline \# Authorsj & 2223 & 7.034188 & 3.41921 & 1 & 34 \\
\hline Total Citationsj & 2223 & 209.60 & 231.22 & 1 & 2543 \\
\hline \multicolumn{6}{|c|}{ CITATION-YEAR CHARACTERISTICS ( $N=27,442$ citation-year observations) } \\
\hline Citation Year $_{\mathrm{jt}}$ & 27442 & 2001.100 & 3.331 & 1993 & 2006 \\
\hline Annual Citations $_{\mathrm{jt}}$ & 27442 & 18.317 & 21.132 & 0 & 336 \\
\hline New Author Citations ${ }_{\mathrm{jt}}$ & 27442 & 11.027 & 13.000 & 0 & 243 \\
\hline Old Author Citations $_{\mathrm{jt}}$ & 27442 & 3.712 & 5.212 & 0 & 58 \\
\hline New Institution Citations ${ }_{\mathrm{jt}}$ & 27442 & 16.616 & 17.427 & 0 & 287 \\
\hline Old Institution Citations $_{\mathrm{jt}}$ & 27442 & 9.671 & 13.346 & 0 & 135 \\
\hline New Key Word Citations $\mathrm{st}_{\mathrm{jt}}$ & 27442 & 70.879 & 65.864 & 0 & 794 \\
\hline Old Key Word Citations $_{\mathrm{jt}}$ & 27442 & 52.252 & 59.326 & 0 & 620 \\
\hline New Journal Citations ${ }_{\mathrm{jt}}$ & 27442 & 7.476 & 7.676 & 0 & 94 \\
\hline Old Journals Citations $_{\mathrm{jt}}$ & 27442 & 5.866 & 7.406 & 0 & 81 \\
\hline Basic Citation $_{\mathrm{jt}}$ & 27442 & 8.725 & 10.942 & 0 & 151 \\
\hline Applied Citation $_{\mathrm{jt}}$ & 27442 & 6.947 & 10.378 & 0 & 157 \\
\hline $\begin{array}{l}\text { All Public Authors } \\
\text { Citation }_{\text {it }}\end{array}$ & 27442 & 15.115 & 17.110 & 0 & 253 \\
\hline $\begin{array}{l}\text { At Least One Private } \\
\text { Author Citation }_{\mathrm{jt}}\end{array}$ & 27442 & 1.349 & 2.697 & 0 & 45 \\
\hline \multicolumn{6}{|c|}{ OPENNESS SHOCK CHARACTERISTICS ( $N=27,442$ citation-year observations) } \\
\hline Post Overall Shock $\mathrm{j}_{\mathrm{jt}}$ & 27442 & 0.0482 & 0.2143 & 0 & 1 \\
\hline Overall Window $_{\mathrm{jt}}$ & 27442 & 0.0147 & 0.1204 & 0 & 1 \\
\hline Post Crelox Shock $\mathrm{jt}_{\mathrm{t}}$ & 27442 & 0.0133 & 0.1144 & 0 & 1 \\
\hline Crelox Window $_{\mathrm{jt}}$ & 27442 & 0.0031 & 0.0552 & 0 & 1 \\
\hline Post Onco Shock ${ }_{\mathrm{jt}}$ & 27442 & 0.0350 & 0.1837 & 0 & 1 \\
\hline Onco Window $_{\mathrm{jt}}$ & 27442 & 0.0117 & 0.1074 & 0 & 1 \\
\hline
\end{tabular}


TABLE 3: SUMMARY STATISTICS BY MOUSE TECHNOLOGY

\begin{tabular}{|c|c|c|c|c|c|}
\hline & & \multicolumn{4}{|c|}{ MOUSE TECHNOLOGY } \\
\hline VARIABLE & $\mathbf{N}$ & CRELOX & ONCO & OTHER GM & SPONTANEOUS \\
\hline \multicolumn{6}{|c|}{ PUBLICATION CHARACTERISTICS ( $N=2,223$ original publication) } \\
\hline Publication Year $_{j}$ & 2223 & 1996.549 & 1991.737 & 1995.448 & 1990.789 \\
\hline \# Authors ${ }_{j}$ & 2223 & 5.250 & 5.944 & 7.341 & 4.718 \\
\hline Total Citations $\mathrm{j}_{\mathrm{j}}$ & 2223 & 158.831 & 228.959 & 234.198 & 68.411 \\
\hline \multicolumn{6}{|c|}{ CITATION-YEAR CHARACTERISTICS ( $\mathrm{N}=\mathbf{2 7 , 4 4 2}$ citation-year observations) } \\
\hline Annual Citations & 27442 & 15.3340 & 13.3326 & 20.9152 & 3.8202 \\
\hline New Author Citations & 27442 & 10.1294 & 7.6285 & 12.5957 & 2.3799 \\
\hline Old Author Citations & 27442 & 2.6305 & 2.2984 & 4.3015 & 0.6584 \\
\hline New Institutions & 27442 & 15.6910 & 11.0114 & 18.9562 & 3.9763 \\
\hline Old Institutions & 27442 & 8.7286 & 6.1850 & 11.1357 & 1.8031 \\
\hline New Key Words & 27442 & 75.4572 & 50.7871 & 80.2499 & 17.5752 \\
\hline Old Key Words & 27442 & 35.7996 & 39.9560 & 59.6379 & 11.1171 \\
\hline New Journal Citations & 27442 & 7.5511 & 4.7736 & 8.5364 & 1.7752 \\
\hline Old Journal Citations & 27442 & 4.7182 & 4.6010 & 6.6681 & 1.2618 \\
\hline Basic Citations & 27442 & 8.8288 & 5.0855 & 9.9965 & 2.1295 \\
\hline Applied Citations & 27442 & 3.3612 & 6.4306 & 7.8953 & 1.2437 \\
\hline $\begin{array}{l}\text { All Public Author } \\
\text { Citations }\end{array}$ & 27442 & 13.2443 & 10.9772 & 17.2503 & 3.1377 \\
\hline $\begin{array}{l}\text { At Least One Private } \\
\text { Author Citations }\end{array}$ & 27442 & 0.7724 & 0.9591 & 1.5539 & 0.2583 \\
\hline
\end{tabular}


TABLE 4: IMPACT OF OPENNESS SHOCKS ON ANNUAL CITATION FLOWS

\begin{tabular}{|c|c|c|c|}
\hline & $\begin{array}{r}\text { De } \\
\text { [Inciden } \\
\text { (Block b }\end{array}$ & $\begin{array}{l}\text { IGATIVE BINON } \\
\text { Ir = ANNUAL CIT } \\
\text { ratios reported in s } \\
\text { nated coefficients in } \\
\text { rapped SEs reported }\end{array}$ & $\begin{array}{l}\text { NS } \\
\text { brackets] } \\
\text { entheses) }\end{array}$ \\
\hline & $\begin{array}{c}\mathbf{( 4 - 1 )} \\
\text { Baseline Model with } \\
\text { Overall Shock } \\
\end{array}$ & $\begin{array}{c}\mathbf{( 4 - 2 )} \\
\text { Overall Shock with } \\
\text { Time Dynamics } \\
\end{array}$ & $\begin{array}{c}\mathbf{( 4 - 3 )} \\
\text { Baseline Model with } \\
\text { Cre \& Onco Shocks } \\
\end{array}$ \\
\hline Post Overall Shock & $\begin{array}{c}{[1.213] * * *} \\
0.1934 \\
(0.0507)\end{array}$ & & \\
\hline $\begin{array}{l}\text { Post Overall Shock } \\
\text { Short-run }\end{array}$ & & $\begin{array}{c}\mathbf{1 . 1 5 2}]^{* *} \\
0.1411 \\
(0.0591)\end{array}$ & \\
\hline $\begin{array}{l}\text { Post Overall Shock } \\
\text { Long-run }\end{array}$ & & $\begin{array}{c}{[1.320]^{* * * *}} \\
0.2773 \\
(0.0777)\end{array}$ & \\
\hline Post Cre-lox Shock & & & $\begin{array}{c}{[\mathbf{1 . 1 7 8}]^{*}} \\
0.1637 \\
0.0919\end{array}$ \\
\hline Post Onco Shock & & & $\begin{array}{c}{[\mathbf{1 . 2 1 2}]^{* * * *}} \\
0.1921 \\
(0.0610)\end{array}$ \\
\hline $\begin{array}{l}\text { Window } \\
\text { - Overall } \\
\text { - Cre } \\
\text { - Onco }\end{array}$ & $\begin{array}{c}\text { [1.119]*** } \\
0.1124 \\
(0.0405) \\
- \\
-\end{array}$ & $\begin{array}{c}\mathbf{1 . 1 2 2}]^{* *} \\
0.1152 \\
(0.0472) \\
- \\
-\end{array}$ & $\begin{array}{c}- \\
{[\mathbf{0 . 9 8 3}]} \\
-0.017 \\
(0.123) \\
{[\mathbf{1 . 1 6 3}]^{* * *}} \\
0.151 \\
0.0448 \\
\end{array}$ \\
\hline Log-likelihood & $\begin{array}{l}-67168.977 \\
\end{array}$ & -67153.037 & -67164.516 \\
\hline \# of Observations & 27428 & 27428 & 27428 \\
\hline
\end{tabular}

Significance levels: * $10 \% * * 5 \% * * * 1 \%$

Coefficients for the Window period are included in all regressions but suppressed in order to focus on key variables in the analysis. IRRs reported in brackets; raw coefficients reported in middle line. 
TABLE 5: IMPACT OF OPENNESS SHOCKS ON CITATIONS

BY NEW VS. OLD 'LAST AUTHORS' \& BY NEW VS. OLD INSTITUTIONS

\begin{tabular}{|c|c|c|c|c|c|c|c|c|}
\hline & \multicolumn{8}{|c|}{$\begin{array}{c}\text { STACKED NEGATIVE BINOMIAL } \\
\text { [Incident rate ratios reported in square brackets] } \\
\text { Estimated coefficients in } 2^{\text {nd }} \text { line. } \\
\text { (Block bootstrapped SEs reported in parentheses) }\end{array}$} \\
\hline & $\begin{array}{l}\text { (5-1a) } \\
\text { DV= } \\
\text { New Author } \\
\text { Citations }\end{array}$ & $\begin{array}{l}\text { (5-1b) } \\
\text { DV= } \\
\text { Old Author } \\
\text { Citations }\end{array}$ & $\begin{array}{l}\text { (5-2a) } \\
\text { DV= } \\
\text { New Author } \\
\text { Citations }\end{array}$ & $\begin{array}{l}\text { (5-2b) } \\
\text { DV= } \\
\text { Old Author } \\
\text { Citations }\end{array}$ & $\begin{array}{c}\text { (5-3a) } \\
\text { DV }= \\
\text { New Author } \\
\text { Citations } \\
\text { With Time Dynamics }\end{array}$ & $\begin{array}{c}\mathbf{( 5 - 3 b )} \\
\text { DV= } \\
\text { Old Author } \\
\text { Citations } \\
\text { With Time Dynamics }\end{array}$ & $\begin{array}{c}\text { (5-4a) } \\
\text { DV= } \\
\text { New } \\
\text { Institution } \\
\text { Citations } \\
\end{array}$ & $\begin{array}{c}(\mathbf{5}-\mathbf{4 b}) \\
\mathrm{DV}= \\
\text { Old } \\
\text { Institution } \\
\text { Citations }\end{array}$ \\
\hline Post Overall Shock & $\begin{array}{c}1.250]^{* * *} \\
0.223 \\
(0.054) \\
\end{array}$ & $\begin{array}{c}{[1.082]} \\
0.0785 \\
(0.0789) \\
\end{array}$ & & & & & $\begin{array}{l}{[1.202]^{* * * *}} \\
0.184 \\
(0.0494)\end{array}$ & $\begin{array}{c}{[1.142]^{* *}} \\
0.133 \\
(0.0612)\end{array}$ \\
\hline $\begin{array}{l}\text { Post Overall Shock } \\
\text { Short-run }\end{array}$ & & & & & $\begin{array}{c}{[1.185]^{* * *}} \\
0.170 \\
(0.0538) \\
\end{array}$ & $\begin{array}{c}0.994] \\
-0.0056 \\
(0.814) \\
\end{array}$ & & \\
\hline $\begin{array}{l}\text { Post Overall Shock } \\
\text { Long-run }\end{array}$ & & & & & $\begin{array}{c}{[1.363]^{* * *}} \\
0.310 \\
(0.0695) \\
\end{array}$ & $\begin{array}{c}1.207]^{* *} \\
0.188 \\
(0.0801) \\
\end{array}$ & & \\
\hline Post Cre-lox Shock & & & $\begin{array}{c}{[1.251]^{* *}} \\
0.224 \\
(0.108) \\
\end{array}$ & $\begin{array}{c}0.992] \\
-0.0083 \\
(0.099)\end{array}$ & & & & \\
\hline Post Onco Shock & & & $\begin{array}{c}1.220]^{* * * *} \\
0.199 \\
(0.067)\end{array}$ & $\begin{array}{c}{[1.127]} \\
0.120 \\
(0.0736)\end{array}$ & & & & \\
\hline \multicolumn{9}{|l|}{ Log-likelihood } \\
\hline \# of Observations & & & & & & & & \\
\hline
\end{tabular}


TABLE 6: IMPACT OF OPENNESS SHOCKS ON CITATIONS WITH NEW VS. OLD KEY WORDS

\begin{tabular}{|c|c|c|c|c|c|c|}
\hline & \multicolumn{6}{|c|}{$\begin{array}{c}\text { STACKED NEGATIVE BINOMIAL } \\
\text { [Incident rate ratios reported in square brackets] } \\
\text { Estimated coefficients in } 2^{\text {nd }} \text { line. } \\
\text { (Block bootstrapped SEs reported in parentheses) }\end{array}$} \\
\hline & $\begin{array}{l}\text { (6-1a) } \\
\text { DV=New } \\
\text { Key Word } \\
\text { Citations }\end{array}$ & $\begin{array}{l}\text { (6-1b) } \\
\text { DV=Old } \\
\text { Key Word } \\
\text { Citations }\end{array}$ & $\begin{array}{c}\text { (6-2a) } \\
\text { DV=New } \\
\text { Key Word } \\
\text { Citations } \\
\text { With Time Dynamics } \\
\end{array}$ & $\begin{array}{c}\mathbf{( 6 - 2 b )} \\
\text { DV= Old } \\
\text { Key Word } \\
\text { Citations } \\
\text { With Time Dynamics } \\
\end{array}$ & $\begin{array}{c}\text { (6-3a) } \\
\text { DV=New } \\
\text { Key Word } \\
\text { Citations }\end{array}$ & $\begin{array}{c}\mathbf{( 6 - 3 b )} \\
\text { DV=Old Key } \\
\text { Word } \\
\text { Citations }\end{array}$ \\
\hline Post Overall Shock & $\begin{array}{c}1.250]^{* * *} \\
0.223 \\
(0.0738) \\
\end{array}$ & $\begin{array}{l}0.977] \\
-0.0230 \\
(0.0732) \\
\end{array}$ & & & & \\
\hline $\begin{array}{l}\text { Post Overall Shock } \\
\text { Short-run }\end{array}$ & & & $\begin{array}{c}{[1.197]^{* * *}} \\
0.180 \\
(0.0586) \\
\end{array}$ & $\begin{array}{c}{[0.926]} \\
-0.0765 \\
(0.0666)\end{array}$ & & \\
\hline $\begin{array}{l}\text { Post Overall Shock } \\
\text { Long-run }\end{array}$ & & & $\begin{array}{c}1.350]^{* * *} \\
0.300 \\
(0.0843)\end{array}$ & $\begin{array}{c}1.052] \\
0.0504 \\
(0.0784)\end{array}$ & & \\
\hline Post Cre-lox Shock & & & & & $\begin{array}{c}1.302]^{* *} \\
0.264 \\
(0.104) \\
\end{array}$ & $\begin{array}{c}{[0.894]} \\
-0.112 \\
(0.112) \\
\end{array}$ \\
\hline Post Onco Shock & & & & & $\begin{array}{c}{[1.202]^{*}} \\
0.184 \\
(0.0965) \\
\end{array}$ & $\begin{array}{l}1.023] \\
0.0225 \\
(0.115) \\
\end{array}$ \\
\hline \multicolumn{7}{|l|}{ Log-likelihood } \\
\hline \# of Observations & & & & & & \\
\hline
\end{tabular}


TABLE 7: IMPACT OF OPENNESS SHOCKS ON CITATIONS

IN NEW VS. OLD JOURNALS

\begin{tabular}{|c|c|c|c|c|c|c|}
\hline & \multicolumn{6}{|c|}{$\begin{array}{l}\text { STACKED NEGATIVE BINOMIAL } \\
\text { [Incident rate ratios reported in square brackets] } \\
\text { Estimated coefficients in } 2^{\text {nd }} \text { line. } \\
\text { (Block bootstrapped SEs reported in parentheses) }\end{array}$} \\
\hline & $\begin{array}{c}\text { (7-1a) } \\
\text { DV }= \\
\text { New Journal } \\
\text { Citations }\end{array}$ & $\begin{array}{l}\text { (7-1b) } \\
\text { DV= } \\
\text { Old Journal } \\
\text { Citations }\end{array}$ & $\begin{array}{c}\text { (7-2a) } \\
\text { DV }= \\
\text { New Journal } \\
\text { Citations } \\
\text { With Time Dynamics } \\
\end{array}$ & $\begin{array}{c}\text { (7-2b) } \\
\text { DV }= \\
\text { Old Journal } \\
\text { Citations } \\
\text { With Time Dynamics } \\
\end{array}$ & $\begin{array}{c}\text { (7-3a) } \\
\text { DV }= \\
\text { New Journal } \\
\text { Citations }\end{array}$ & $\begin{array}{l}\text { (7-3b) } \\
\text { DV }= \\
\text { Old Journal } \\
\text { Citations }\end{array}$ \\
\hline Post Overall Shock & $\begin{array}{c}{[1.237]^{* * *}} \\
0.213 \\
(0.0711) \\
\end{array}$ & $\begin{array}{c}{[1.108]} \\
0.103 \\
(0.0706) \\
\end{array}$ & & & & \\
\hline $\begin{array}{l}\text { Post Overall Shock } \\
\text { Short-run }\end{array}$ & & & $\begin{array}{c}{[1.223] * * *} \\
0.201 \\
(0.0546) \\
\end{array}$ & $\begin{array}{c}{[1.022]} \\
0.0213 \\
(0.0599) \\
\end{array}$ & & \\
\hline $\begin{array}{l}\text { Post Overall Shock } \\
\text { Long-run }\end{array}$ & & & $\begin{array}{c}1.274]^{* * *} \\
0.242 \\
(0.0776) \\
\end{array}$ & $\begin{array}{c}{[1.234]^{* * *}} \\
0.210 \\
(0.0764) \\
\end{array}$ & & \\
\hline Post Cre-lox Shock & & & & & $\begin{array}{c}1.235] \\
0.211 \\
(0.145) \\
\end{array}$ & $\begin{array}{c}1.105] \\
0.100 \\
(0.133) \\
\end{array}$ \\
\hline Post Onco Shock & & & & & $\begin{array}{c}{[1.236]^{* * *}} \\
0.212 \\
(0.065) \\
\end{array}$ & $\begin{array}{c}1.108] \\
0.103 \\
(0.087) \\
\end{array}$ \\
\hline \multicolumn{7}{|l|}{ Log-likelihood } \\
\hline \# of Observations & & & & & & \\
\hline
\end{tabular}


TABLE 8: IMPACT OF OPENNESS SHOCKS ON CITATIONS

IN BASIC VS. APPLIED JOURNALS

\begin{tabular}{|c|c|c|c|c|c|c|}
\hline & \multicolumn{6}{|c|}{$\begin{array}{c}\text { STACKED NEGATIVE BINOMIAL } \\
\text { [Incident rate ratios reported in square brackets] } \\
\text { Estimated coefficients in } 2^{\text {nd }} \text { line. } \\
\text { (Block bootstrapped SEs reported in parentheses) }\end{array}$} \\
\hline & $\begin{array}{c}\text { (8-1a) } \\
\text { DV= } \\
\text { Basic Journal } \\
\text { Citations }\end{array}$ & $\begin{array}{c}\text { (8-1b) } \\
\text { DV= } \\
\text { Applied Journal } \\
\text { Citations }\end{array}$ & $\begin{array}{l}\text { (8-2a) } \\
\text { DV= } \\
\text { Basic Journal } \\
\text { Citations }\end{array}$ & $\begin{array}{c}\text { (8-2b) } \\
\text { DV= } \\
\text { Applied Journal } \\
\text { Citations }\end{array}$ & $\begin{array}{c}\mathbf{( 8 - 3 a )} \\
\text { DV= } \\
\text { Basic Journal } \\
\text { Citations } \\
\text { with Time Dynamics } \\
\end{array}$ & $\begin{array}{c}\mathbf{( 8 - 3 b )} \\
\text { DV= } \\
\text { Applied Journal } \\
\text { Citations } \\
\text { with Time Dynamics } \\
\end{array}$ \\
\hline Post Overall Shock & $\begin{array}{c}1.225]^{* * *} \\
0.203 \\
(0.0732) \\
\end{array}$ & $\begin{array}{c}{[1.184]^{* *}} \\
0.169 \\
(0.0766) \\
\end{array}$ & & & & \\
\hline Post Cre-lox Shock & & & $\begin{array}{c}{[1.777]^{* * *}} \\
0.575 \\
(0.0975) \\
\end{array}$ & $\begin{array}{c}{[0.797]^{*}} \\
-0.2269 \\
(0.117) \\
\end{array}$ & & \\
\hline Post Onco Shock & & & $\begin{array}{c}{[1.029]} \\
0.029 \\
(0.0611) \\
\end{array}$ & $\begin{array}{c}{[1.562]^{* * *}} \\
0.446 \\
(0.0739) \\
\end{array}$ & & \\
\hline $\begin{array}{l}\text { Post Cre-lox Shock } \\
\text { Short-run }\end{array}$ & & & & & $\begin{array}{c}1.631]^{* * *} \\
0.4891 \\
(0.0914)\end{array}$ & $\begin{array}{c}0.745]^{* *} \\
-0.2950 \\
(0.1196)\end{array}$ \\
\hline $\begin{array}{l}\text { Post Cre-lox Shock } \\
\text { Long-run }\end{array}$ & & & & & $\begin{array}{c}2.140]^{* * *} \\
0.7606 \\
(0.1178) \\
\end{array}$ & $\begin{array}{l}{[0.915]} \\
-0.0889 \\
(0.1522) \\
\end{array}$ \\
\hline $\begin{array}{l}\text { Post Onco Shock } \\
\text { Short-run }\end{array}$ & & & & & $\begin{array}{c}{[1.030]} \\
0.0298 \\
(0.0756)\end{array}$ & $\begin{array}{c}1.514]^{* * *} \\
0.4150 \\
(0.0788)\end{array}$ \\
\hline $\begin{array}{l}\text { Post Onco Shock } \\
\text { Long-run }\end{array}$ & & & & & $\begin{array}{c}{[1.029]} \\
0.0290 \\
(0.0861) \\
\end{array}$ & $\begin{array}{c}{[1.632]^{* * *}} \\
0.4898 \\
(0.1050) \\
\end{array}$ \\
\hline \multicolumn{7}{|l|}{ Log-likelihood } \\
\hline \# of Observations & & & & & & \\
\hline
\end{tabular}

